University of Chicago Law School

Chicago Unbound

Journal Articles

Faculty Scholarship

1986

\title{
Waiting for Rescue: An Essay on the Evolution and Incentive Structure of the Law of Affirmative Obligations
}

Saul Levmore

Follow this and additional works at: https://chicagounbound.uchicago.edu/journal_articles

Part of the Law Commons

\section{Recommended Citation}

Saul Levmore, "Waiting for Rescue: An Essay on the Evolution and Incentive Structure of the Law of Affirmative Obligations," 72 Virginia Law Review 879 (1986).

This Article is brought to you for free and open access by the Faculty Scholarship at Chicago Unbound. It has been accepted for inclusion in Journal Articles by an authorized administrator of Chicago Unbound. For more information, please contact unbound@law.uchicago.edu. 


\section{VIRGINIA LAW REVIEW}

VOLUME 72

August 1986

NUMBER 5

WAITING FOR RESCUE: AN ESSAY ON THE EVOLUTION AND INCENTIVE STRUCTURE OF THE LAW OF AFFIRMATIVE OBLIGATIONS

\section{Saul Levmore*}

7 HE legal distinction between omissions and commissions is useful but vulnerable. It is easy to point out that commissions are indistinguishable from omissions because both may be excused in a similar fashion. Every law student learns that omissions sometimes lead to liability, as when physicians may be liable for failing to employ certain procedures, and that negligent commissions occasionally do not lead to liability, as may be the case when a landowner's commissions injure a trespasser. ${ }^{1}$ The clever law student is even able to turn commissions into omissions by arguing, for example, that negligent driving is nothing more than the failure to brake. Despite its vulnerabihty, however, the omission-commission distinction survives as a useful descriptive tool. The common law will, for example, neither penalize one who fails to rescue a stranger from drowning nor normally impose liability on someone who fails to disclose information as regularly as it will penalize one who affirmatively misdiscloses. ${ }^{2}$ The existence or non-existence of a

* Professor of Law, University of Virginia. I am indebted to Glen Robinson, Roberta Romano, Robert Scott, Helen Snyder, and participants at a Law and Economics Workshop at Harvard and a Legal Studies Workshop at the University of Virginia for many constructive suggestions and conversations.

${ }_{1}^{1}$ See generally W. Prosser \& W. Keeton, The Law of Torts $\$ 56$ (5th ed. 1984) (discussing the omission-commission distinction in American tort law).

${ }^{2}$ See id. at 373-74 (liability for omission often based on the finding of a special relationship); see also Weinrib, The Case for a Duty to Rescue, 90 Yale L.J. 247 n.1 (1980) (listing several special relationships). 
"duty" is said to explain the imposition of liability in some of these cases, but this duty appears inseparable from the question of whether a commission or an omission is at issue. ${ }^{3}$ Although new duties have been imposed over time, ${ }^{4}$ the overall impression has remained relatively constant; our legal system is seen as one that regularly deters antisocial commissions, often compensates victims of commissions, rarely deters antisocial omissions, and virtually never rewards rescuers. ${ }^{5}$ It is sometimes said that the law's absolution of nonrescuers reflects a disinclination to legislate morality. ${ }^{6}$ But this is an inadequate explanation of the law because wrongful commissions are the stuff of both legislation and moral outlooks. What, then, does explain the often criticized disinclination to impose a duty to rescue, a duty to disclose information, a duty to return (rather than ignore) lost property, and other affirmative obligations? Although the treatment of rescue is not necessarily related to that of other matters easily tied to the omission-commission distinction, it is useful to focus mainly on rescue and to expect that a better understanding of this "nonobligation" will inform others. It is especially intriguing to focus on the duty to rescue in light of the fact that so many other legal systems do penalize one who fails to rescue. ${ }^{7}$

In this essay I suggest three themes, or arguments, that inform the omission-commission distinction in general, and the treatment of rescue in particular. Although these arguments are interactive,

${ }^{3}$ See Handiboe v. McCarthy, 114 Ga. App. 541, 151 S.E.2d 905 (1966) (child drowning in pool); Osterlind v. Hill, 263 Mass. 73, 160 N.E. 301 (1928) (drowning); Yania v. Bigan, 397 Pa. 316, 155 A.2d 343 (1959) (drowning); W. Prosser \& W. Keeton, supra note 1, § 106, at 737-38 (collecting nondisclosure cases).

- See infra notes 46.65 and accoinpanying text.

' See Dawson, Rewards for Rescue of Human Life?, in The Good Samaritan and the Law 63 (J. Ratcliffe ed. 1966)

- See 1 F. Lawson \& B. Markesinis, Tortious Liability for Unintentional Harm in the Common Law and the Civil Law 72 (1982); Gregory, The Good Samaritan and the Bad: The Anglo-American Law, in The Good Samaritan and the Law, supra note 5, at 23.

7 See Feldbrugge, Good and Bad Samaritans: A Comparative Survey of Criminal Law Provisions Concerning Failure to Rescue, 14 Am. J. Comp. L. 630 (1966); Rudzinski, The Duty to Rescue: A Comparative Analysis, in The Good Samaritan and the Law, 91, 108-15, supra note 5 , at 23 . German courts have allowed recovery of a rescuer's expenses. The Austrian, Polish, and Czech Civil Codes explicitly allow a rescuer to recover his expenses. Portugal, Holland, Italy, Norway, Soviet Union, Turkey, Denmark, Poland, Germany, Rumania, France, Hungary, and Czechoslovakia have statutes that create a general duty to rescue. Id. at 91 n.3. 
they are best developed separately. Part I explores the behavioral effects of rules affecting potential rescuers. The discussion considers the rewards and penalties that may be imposed to encourage rescues and seeks to explain why, in fact, we find an interesting symmetry in most legal systems: "sticks" (penalties for nonrescue) accompany "carrots" (rewards for rescue) and the absence of sticks seems to be correlated with the denial of carrots. Part II applies a theme developed elsewhere ${ }^{8}$ and argues that the variety that is found among different legal systems in the treatment of rescue and in our own system's treatment of finders, disclosers, and salvors at sea is largely within a predictable range. This variety may reflect different conjectures about various behavioral effects as much as it is a product of historical accidents or diverse cultural and political attitudes. ${ }^{\circ}$ The parallel analyses of the rules pertaining to finders, disclosers, salvors, and more familiar rescuers-all of whom must decide whether to take affirmative steps-highlights the usefulness of thinking about the behavioral effects of legal tools.

The discussion in Part III considers the likely evolution of the treatment of rescue in American law and suggests that experimentation with or evolution of the use of penalties may have been impeded by our legal system's need to develop first its approach to "multiple commission" problems. Now that a number of doctrinal steps have been taken to allocate liability among multiple tortfeasors, or committers, there is some reason to think that the allocation among potential omitters, and therefore the development of a more general duty to rescue, will not be far behind. I do not go so far as to predict a developing obligation to donate money to the poor; indeed, it is easy to predict that there will continue to be no obligation to do that which a legislature or society as a whole could easily do. But I do conclude that there will continue to develop an obligation on the part of persons especially well situated to effect easy rescues. ${ }^{10}$

- Levmore, Rethinking Comparative Law: Variety and Uniformity in Ancient and Modern Tort Law 1-6 (1986) (unpublished manuscript on file with Virginia Law Review Association).

- See infra text accompanying note 44.

10 Although I do not undertake to examine the parameters of easy rescue, it is clear that as such an obligation develops the law will need to define the level of risk that a potential rescuer must absorb, and this definition will surely reflect process-cost considerations. As will become clear, many obligations already required by the law impose such process costs. 


\section{The Incentive Structure for Rescue}

Rewards and penalties will motivate a potential rescuer only if he is aware of these incentives and then only if in a crucial moment he is able to be influenced by this knowledge. Although there is some reason to believe that citizens are aware of the rules regarding rescue and that many rescues require prepositioning or afford time for contemplation, arguments for and against various rules must surely rest on a sense that incentives work on the margin. ${ }^{11}$ I do not argue in this essay that one set of rules will best promote socially desirable rescues or, indeed, that these penalties and rewards have substantial behavioral-as opposed to symbolic-effects. I imagine, instead, that lawmakers will try to promote certain kinds of behavior with legal rules and will be especially eager to enact rules that either work on the margin or are, at worst, harmless. ${ }^{12}$ This is a positive and not a normative exercise.

The law could, of course, simply give a successful rescuer a reward for his deed. This "carrot" might be paid by the rescued victim, by the state, or by some third party. If the rescue is of property rather than life, as when a rescuer brings a fire under control and prevents further loss of property, then this reward could easily be varied according to the value of the property saved. Rewards for the rescue of life or property could be very substantial, sufficient to promote the equivalent of a competitive industry of rescuers, or barely enough to cover the rescuer's expenses. It is easy to quibble with this classification and insist that mere reimbursement of expenses simply erases a penalty otherwise incurred by a rescuer, but both because these expenses are not imposed by the law and because the rescuer may well regard a package of reimbursement, public acclaim, and private gratitude as a substantial carrot, it is convenient to think of a legal right to reimbursement as a reward. Apart from any other rewards, the law could exempt rescuers from liability for some or all of the injuries they happen to impose while engaged in their rescue..$^{13}$ Finally, rescuers who are themselves in-

1 Zeisel, An International Experiment on the Effects of a Good Samaritan Law, in The Good Samaritan and the Law, supra note 5, at 209, 210 (German, Austrian, and American residents displayed fair knowledge of their respective countries' rescue laws).

12 Some rewards may be harmless in the sense that even if they do not stimulate desirable rescues it is unlikely that they would suppress such rescues.

1s Every state has adopted some form of legislation that restricts the liability of partici- 
jured while attempting to render assistance could be allowed to collect from the victim (whether or not actually rescued) or some other party. ${ }^{14}$

The available penalties are even simpler to sketch. The law must, if it seeks to penalize nonrescuers, first identify a nonrescuer and then provide some penalty, or "stick." Both because penalties are often contained within the criminal law, where doubts are usually resolved in favor of the accused, and because it would defeat the instrumental purpose of the law to punish nonrescue too seriously, ${ }^{16}$ the identification of nonrescuers is usually limited to persons who should realize that they could easily take some step to save life or valuable property. ${ }^{16}$ It is very unlikely, for instance, that any legal system would penalize someone who only called the police--even though a more direct step would have been inore useful-or who genuinely believed that some other onlooker had already called for help. ${ }^{17}$ Once a nonrescuer is identified, the penalty

pants in rescue operations. See Comment, Good Samaritan Laws-The Legal Placebo: A Current Analysis, 17 Akron L. Rev. 303 (1983).

14 See Wagner v. International Ry. Co., 232 N.Y. 176, 133 N.E. 437 (1921) (allowing an unsuccessful rescuer to recover for his injuries from a neghigent third party).

1s See infra text accompanying notes $31-33$.

18 For example, the Vermont and West German statutes are illustrative of the empbasis in duty-to-rescue laws on encouraging easy or simple rescues. Vt. Stat. Ann. tit. 12, § 519 (1973):

a) A person who knows that another is exposed to grave physical harm shall, to the extent that the same can be rendered without danger or peril to himself or without interference with important duties owed to others, give reasonable assistance to the exposed person unless that assistance or care is being provided by others.

b) A person who provides reasonable assistance in comphance with subsection (a) of this section shall not be liable in civil damages unless his acts constitute gross negligence or unless he will receive or expects to receive remuneration. Nothing contained in this subsection shall alter existing law with respect to tort hability of a practitioner of the healing arts for acts committed in the ordinary course of his practice.

c) A person who willfully violates subsection (a) of this section shall be fined not more than $\$ 100.00$.

German Criminal Code Art. 330c:

Anyone who does not render aid in an accident or common danger or in an emergency situation, although aid is needed and under the circumstances can be expected of him, especially if he would not subject himself thereby to any considerable danger, or if he would not thereby violate other important duties, shall be punishable by deprivation of liberty for a term not to exceed one year or a fine.

Library of Congress Law Library, Good Samaritan Laws in France, the Federal Republic of Germany, and USSR I1 (1976) (footnotes omitted).

17 Some legal systems specifically offer a potential rescuer the choice of informing the proper authority or undertaking a rescue. See Rudzinski, supra note 7, at 108 (reviewing 
that is imposed can vary over a familiar range; nonrescuers can be fined or incarcerated, held civilly liable for the injury that befalls the unassisted victim, or both. ${ }^{18}$

\section{A. Landes and Posner's Arguments}

Any discussion of the likely behavioral effects of the carrots and sticks that might be offered to rescuers best begins with three points made by Professors Landes and Posner in their well-known work on the law and economics of rescue. ${ }^{19}$ They argue that: (1) an excessively large reward will sometimes lead to inefficient consequences because victims or owners will take excessive precautions to avoid paying such rewards; ${ }^{20}$ (2) a rescuer may be motivated by altruism or by the possibility of being regarded as a hero, and that legal inducements can impede this motivation; ${ }^{21}$ and (3) excessive penalties can decrease the number of rescues because potential rescuers may avoid potential "rescue spots," such as beaches, in order to avoid the reach of these penalties. ${ }^{22}$ The discussion that follows emphasizes the importance of the first of these arguments, discounts the second, and then explores in greater depth the likely effects of various legal rules governing rescue.

The first of Landes and Posner's points is not controversial and is easy to illustrate. If $\mathrm{A}$ can hire a watchman at a cost of $\$ 10,000$ per year but a passerby (or even a professional rescuer) can save A's $\$ 100,000$ property from fire at an average cost of $\$ 500$ per event-and such an event is likely to occur once a year-then $A$ will inefficiently (at excessive expense) hire the guard if he knows the law will require him to pay strangers who come to the rescue a commission of, say, one-third or one-half of the value of the property they save. Landes and Posner point out that under admiralty

Italian, Turkish, Rumanian, and Russian law). But the point in the text is simply that it is difficult to imagine (and I have found no) prosecutions of persons who called for help but did not take other actions themselves.

${ }^{18}$ See id. at 110-14; infra notes 114-17 and accompanying text; infra notes 121-26 and accompanying text.

${ }^{19}$ Landes \& Posner, Salvors, Finders, Good Samaritans, and Other Rescuers: An Economic Study of Law and Altruism, $7 \mathrm{~J}$. Legal Stud. 83, 91-92 (1978).

${ }^{20}$ Id. at 91-93.

21 Id. at 94,124 .

22 Id. at 119-24. 
law salvors at sea are indeed not rewarded so greatly as to encourage excessive precautions by shipowners; instead, they are probably rewarded at a rate that gives them only a modest return on their investment. ${ }^{23}$ Admiralty law could provide for simple reimbursement of all salvage efforts, instead of granting expenses plus a premium to successful rescuers, but this approach would require factfinders to separate out those who truly tried to rescue the distressed at sea from those who simply announce that they expended effort while the rescue was accomplished by another party or not at all. ${ }^{24}$ In short, admiralty law seems to contain just the sort of incentives for "rescue," or voluntary action, that one would predict on the basis of Landes and Posner's insight that excessive rewards will lead to excessive precautions.

It is more difficult to evaluate the argument that legal incentives may interfere with the utility of altruism as an incentive. In some sense, the same can be said of most tort and criminal law rules; their enactment may counterproductively lead to misbehavior on the part of persons who respond better to untainted, extralegal stimulants. ${ }^{25}$ It is, of course, difficult to measure or intuit the strength of altruism as an incentive in various contexts. I think it safe to intuit as little as possible and to imagine that legal sanctions might interfere with whatever it is that already motivates some rescuers. Large penalties for nonrescue, while stimulating some rescue efforts, might decrease the total number of rescue attempts if rescuers motivated by altruism realize that they will

23 Id. at $100-06$

24 Id. at 104.

25 It is arguable that Landes and Posner's altruism argument is too broad for its own good because it comes close to suggesting that all behavior might better be channelled by interpersonal appeals than by legal sanctions. But most citizens would hardly think that horrible acts should generally be decriminalized (in order to encourage potential criminals to behave well) or that those who fail to pay taxes should be encouraged to do otberwise by extralegal inducements alone. On the other hand, an important difference between rescue and tort or criminal cases is that in tort and criminal settings it is hard for a well-hehaved actor to feel like a hero, for so many citizens have refrained from misdeeds. Potential rescuers may feel more unique and, tberefore, better about doing the good thing. This notion, that altruism may be stifled by legal regulation, is not quite tbe same as the idea of "overjustification" in the psychology literature. See Lepper, Green \& Nisbett, Undermining Children's Intrinsic Interests with Extrinsic Rewards: A Test of the Overjustification Hypothesis, 28 J. Pers. Soc. Psychology 129 (1973) (children not initially rewarded for an activity more hikely to engage later in same activity). There the focus is on a given person's repeating certain behavior, whereas in rescue it is unlikely that one individual will be a repeat player. 
sometimes be perceived as having acted only to avoid legal sanctions. On the other hand, rewards should not generate such an effect. A rescuer can always decline a reward and enjoy pure hero status.

Finally, Landes and Posner's second and third arguments can usefully be combined. In considering packages of carrots and sticks that might be aimed at potential rescuers it seems sensible to reject a "large sticks and no carrots" package. Not only would a large penalty interfere with the incentive to be altruistic (or to be regarded as altruistic) but also, when unaccompanied by a large carrot, it might discourage potential rescuers from frequenting potential rescue spots if such spots can indeed be identified in advance. With these points in mind, it is now possible to generalize about those legal packages of rewards and penalties that might sensibly promote desirable rescues and then to explore further the notion that penalties may discourage potential rescuers.

\section{B. Rewards}

Large carrots seem unwise for a number of reasons. First, there is the potential inefficiency, just noted, of swimmers or other potential rescuees' taking excessive precautions to avoid liability. Carrots that are not financed by rescuees will, of course, not lead to precautions on their part. Moreover, private carrots may need to be somewhat more generous than publicly financed carrots because potential rescuers may fear that rescuees will be unable to pay whatever reward is required by law. This first argument against large carrots is thus limited to those that are privately financed.

Second, there is a moral hazard that potential rescuers will create the demand for their own services. This moral hazard is surely more serious in some settings than in others. It is, for example, easier to imagine that carrot-seekers might put holes in strangers' boats and then later rush out to the rescue and reward than it is to see just how such a wrongdoer might encourage swimming accidents. Even when the moral hazard seems quite plausible, it might be avoided if the carrots that are offered to rescuers are not terribly large or, more interestingly, either not in a generally useful currency or accompanied by sticks. ${ }^{28}$ Thus, Good Samaritan statutes

${ }^{28}$ These sticks must be aimed at the moral hazard rather than at the failure to rescue. There must, for example, be a real deterrent to putting holes in strangers' boats. 
do not generate moral hazard problems because they concern carrots that are in a sufficiently peculiar currency (enhanced reputation) to ensure that mischievous intermeddlers cannot profit monetarily from a planned emergency. ${ }^{27}$ The moral hazard problem is also more serious if the carrots are publicly financed, for parties may be tempted to stage emergencies and rescues at the expense of the fisc.

There is yet another reason why it might be sensible for the law not to provide large rewards to rescuers. In developing this argument it will be useful to define a subset of "customized carrots": these are rewards, often tailor made, offered when specific rescues are needed. Thus, while successful salvors at sea normally earn uncustomized and longstanding carrots as provided by admiralty law, ${ }^{28}$ one who returns a lost bracelet to its owner may be entitled to a reward if the owner has advertised and thereby offered a customized carrot. ${ }^{29}$ That jewelry owners in general do not promise rewards to be paid in the event of future losses, and do not press for legislation that promises such rewards, may reflect the moral hazard or even the excessive precautions that such promises might generate. Standing rewards may encourage theft followed by requests for rewards and excessive precautions against loss in the first place.

But consider, now, those settings in wbich excessive precautions are no longer at issue; something has already been lost or is otherwise at risk and the party who is in need of "rescue," such as the owner of a lost bracelet, offers a customized carrot. That such a party may have taken suboptimal, optimal, or even excessive care is now largely irrelevant. On the other hand, the moral hazard that may be generated by carrots is quite relevant and suggests the need for legal intervention. After all, while it is understandable that one who has property in peril will assess the danger that a reward will cause more of his property to be perilized as relatively small, this party is unlikely to consider the hazard that other citizens' property is put at risk. Inasmuch as a reward might en-

27 Additionally, these statutes are often limited to professional health care providers who have no great incentive to cause roadside emergencies in order to earn fees. See infra text following note 141 .

2s See infra notes 104 and accompanying text; infra note 112 and accompanying text.

29 See infra note 191 and accompanying text. 
courage potential "rescuers" to stimulate demand for their own services by other private parties who might be expected to offer and finance large rewards, the law might forbid any party in need of help to offer a carrot. It may, indeed, come to pass one day that laws are effected that prohibit victims from meeting the demands of kidnappers, blackmailers, and extortionists. On the other hand, some combination of empathy for the immediate victims of such demands, concern that kidnappers (for instance) are actually captured precisely because we allow ransoms to be paid (and followed), and suspicion that such prohibitions would be impossible to enforce may overcome any hope that the banning of carrots will lead to a decrease in the crimes that create much of the demand for rescues.

I do not mean to predict the evolution of the law in this regard. The utility of customized carrots is, after all, limited to situations in which there is time and manner for those in need of assistance to communicate with potential rescuers. ${ }^{30}$ My point is simply that the possibility of customized carrots is yet another reason why one should not expect to see longstanding offers of large (uncustomized) carrots. So long as citizens are permitted and the government itself is able to offer customized carrots, it is understandable that the law is less inclined to put in place standing offers of carrots to rescuers. Such carrots may generate excessive precautions where voluntary customized carrots will not. Moreover, customized carrots may create less of a moral hazard problem than carrots that are announced in advance of any specific emergency. To be sure, because potential rescuers may not always learn about the availability of customized carrots, such carrots may not always motivate rescue efforts as forcefully as would carrots that are more generally announced and available. But occasional customized carrots are surely better than no carrots at all.

In short, large carrots may best be reserved for customized offerings in settings in which the probability of successful rescue is low, the investment required of rescuers is great, or the temptation to misbehave (rather than return lost valuables, for example) may be

so On the other hand, it may be that when time is short incentives are generally not terribly useful in promoting desirable rescues. Potential rescuers may best respond to incentives when there is time to consider the offer, the potential risks, and the likelihood of success. When such time is available, custemized carrots can usually be offered. 
serious. Carrots might be forbidden when they threaten to promote an undesirable activity, such as kidnapping or extortion, especially if the enforceability of such a prohibition could somehow be ensured. But whether society has chosen to allow victims to offer private customized carrots because the plight of those in need of rescue is especially compelling, because any prohibition would be too difficult to enforce, or even because private carrots often lead to the capture of criminals, this choice militates against the regular provision of large carrots to all rescuers.

\section{Penalties}

The imposition of large penalties for the failure to rescue may also be unwise. Landes and Posner point out that rescuers may be motivated by glory (or by nothing at all) and that sanctions for nonfeasance may actually destroy this useful incentive. We do, after all, rarely regard an act as heroic when it was encouraged by the threat of punishment for inaction. Unfortunately, it is difficult to know when, if ever, legal sanctions are for this reason counterproductive. It is surely unlikely that fewer car accidents or murders would take place if we would withdraw the legal rules governing such events and rely on altruism to control behavior. On the other hand, it is conceivable that those persons who are most likely to undertake rescues respond differently to similar stimuli than those who are most likely to commit murders and torts, so that it is only the potential rescuers who behave worse when facing large penalties.

A more compelling reason to think that penalties for nonrescue may be counterproductive derives from the fact that criminal or civil liability for nonrescue can hardly extend to someone who was far from the scene of an emergency and in no position at all to act. The threat of a big stick or any stick at all may, as Landes and Posner argue, discourage potential rescuers from nearing potential rescue spots., ${ }^{31}$ This second argument posits an "activity-level effect"; potential rescuers must care about the low probability that an emergency will occur, imagine a significant probability that factfinders will err after the fact and find that the defendant should have known that a rescue was necessary and easy, and cor-

"1 See Landes \& Posner, supra note 19, at 119-24. 
rectly believe that rescues are more likely to be needed in some locations than others.

It may be useful to see that the argument that penalties for nonrescue are unwise because they threaten altruistic rescues presupposes a substantial activity-level effect. Consider, for example, a member of the Girl Scouts who is altruistically motivated to sell cookies every year for the greater good of Scouting. If a penalty such as suspension from the troop is imposed for subpar performance, various effects can be imagined. The scout may certainly ignore the sanction and continue to be motivated by altruistic impulses or may take note of the sanction and increase her efforts because of a fear that she will be judged a shirker. She may, alternatively, be put off by the sanction and resign from the troop, thus demonstrating the existence of an activity-level effect. But apart from such an activity-level effect it is most unlikely that cookie sales or other efforts will decrease. It is difficult to imagine a scout who will continue in the troop but decrease her sales efforts, unless there are steps to be taken that will fool the monitor but really detract from sales. ${ }^{32}$ Indeed, the only appealing example of identifiable rescue spots and, therefore, of a counterproductive activitylevel effect concerns beaches, but one can barely imagine evening strolls on the beach decreasing if potential strollers feared that in the event of a drowning they would be identified as having passed within earshot of the victim. It is difficult to imagine potential rescuers identifying and avoiding other such prime rescue spots and more difficult still to imagine their continuing to frequent such spots but somehow putting less effort into rescue missions that arise because of the imposition of penalties for nonrescue. In short, both arguments concerning the counterproductive aspects of sticks for nonrescue build on the questionable proposition that there can be a substantial activity-level effect, or that rescue spots can be identified and will be avoided. ${ }^{33}$

32 But in the case of professional health care providers, defensive medicine does come to mind. A physician who would on her own have undertaken rescue efforts but resents the imposition of a duty to rescue may, one can imagine, do a poor job of the required rescue. Even this possibility seems safe to ignore for the purposes of this article.

${ }^{33} \mathrm{My}$ intuition is that the problem of legal sanctions' leading to a decrease in rescue efforts is an insignificant one. It is difficult, however, to find everyday examples that support or cast doubt on this intuition. I might argue, for instance, that if the activity-level effect on rescuers were serious, then witnesses to both criminal and civil matters who volun- 
Finally, note that any activity-level effect that is generated by penalties can almost surely be offset by coexisting rewards. Scouts can be encouraged to remain in or even join the troop by carrots for high sales or sales efforts. And it is most unlikely that the presence of these carrots will so destroy the atmosphere of altruism as to lead to a decrease in the desired efforts, for nothing stops the altruistic scout or beach stroller from declining or donating her reward and feeling doubly altruistic.

\section{The Balance Between Carrots and Sticks}

American law does not penalize nonrescuers ${ }^{34}$ and seems to provide virtually no carrots for rescuers. ${ }^{35}$ In contrast, many civil law systems provide substantial sticks, in the form of criminal (and sometimes accompanying civil) liability, to discourage nonrescue. These systems, however, tend also to impute a "mandate", or agency relationship, between rescuer and rescuee and to require the latter to reimburse the former for expenses that the "principal" would surely have authorized..$^{36}$ There is, in short, some evidence of symmetry, or of balance, between carrots and sticks-the systems that penalize nonrescue offer at least reimbursement to rescuers. I explore this balance in some detail in this article. In Part $I$ the durability of this balance is investigated in a discussion

tarily come forward should be exempt from perjury charges. After all, potential witnesses might avoid the very low probability of perjury charges arising out of their testimony much as it is suggested that potential rescuers will avoid the beaches. But this analogy is open to two objections. First, after-the-fact error (by fact-finders or prosecutors) may be perceived as far less likely when intentional wrongs (like perjury) are involved. And, second, it might be argued that the number of perjury prosecutions (of voluntary witnesses) is so low that there is virtually no fear at all of this penalty and therefore no activity-level effect to be analogized to walking on the beach.

A counterproductive activity-level effect may be a bit easier to imagine if the behavior of risk-averse potential rescuers is considered. Even the smallest probability of the smallest stick may discourage a very risk-averse person from abandoning the security of his own home. Inasmuch as my own experience with people contradicts such behavioral assumptions, my inclination in this and in other inquiries is simply to ignore both the conveniences and complications offered by the assumption of substantial risk aversion. A reader with different inclinations must adjust various aspects of the analysis that follows and emerge with a different "balance" between sticks and carrots than that which is developed in this article.

${ }^{34}$ See, e.g., Yania v. Bigan, $397 \mathrm{~Pa}$. 316, 155 A.2d 343 (1959) (no duty to rescue drowning companion).

${ }^{35}$ See Dawson, supra note 5 , at 63.

so See Dawson, supra note 5 , at 63 ; Rudzinski, supra note 7 , at $115-16$. 
of the carrots and sticks that are provided in a variety of legal systems. But first, the discussion in this section explores at a theoretical level the mix of carrots and sticks. I suggest that through a process of elimination one is inclined to expect at least a rough balance in the design of incentives for rescue.

The disadvantages of large carrots alone, especially in the context of a legal system that permits and presupposes customized carrots, have already been discussed. ${ }^{37}$ I have also argued that small sticks are unlikely to generate important activity-level effects. ${ }^{38}$ Very large sticks, such as long-term incarcerations, are, of course, very costly to the society that imposes them. In any event, until there is evidence that some society increases the penalties imposed on nonrescuers because of dissatisfaction with the effects of small penalties, it seems sensible to limit the present discussion to the availability of small sticks, such as fines or the threat of civil liability. These penalties need not always be imposed; occasional judgments against nonrescuers may, like a rule of partial liability, be large enough to stimulate some rescues and small enough to avoid substantial activity-level effects. And even if sticks inevitably generate counterproductive activity-level effects, it seems likely that modest carrots can offset these sticks by raising the activity level that sticks may depress. To be sure, these carrots may generate their own problems, but the point is that some balance between the dangers of carrots and the activity-level effects of sticks might be sought.

It appears, then, that large carrots alone are unwise and that sticks alone are inferior to sticks accompanied by activity-inducing carrots. By "large carrots" I mean only to point out that the disadvantages of carrots are almost surely a function of their size; indeed, I will now refer to "carrots" alone and mean to imply a presumption that they not be large. One is left with the following alternatives: (1) "sticks and carrots"; (2) "no sticks and no carrots"; and (3) "carrots and no sticks." The first package is symmetrical, or balanced, and is close to what is found in most civil law countries. ${ }^{39}$ The second package is also balanced and fits the usual description of American law. One might dispute this description

\footnotetext{
37 See supra text following note 27 .

38 See supra text accompanying notes 31-33.

38 See infra notes $114-30$ and accompanying text.
} 
and argue that because American culture exalts rescuers, and because state statutes in the United States generally exempt some rescuers from tort liability, it is the third package that most accurately characterizes American law. But because I mean to focus on carrots that are larger than those provided through Good Samaritan statutes and cultural attitudes toward heroism, I ask the reader who believes that Good Samaritan statutes contain important or substantial carrots to rephrase the third stick-and-carrot package in a way that permits one to pose what I regard as an important unanswered question: Why do we appear to find (1) "sticks and carrots" and (2) "no sticks and virtually no carrots" when it would seem that (3) "carrots and no sticks" is a package that is to be preferred to package (2)? Again, the power of altruism as a motivation to rescue is not something that argues strongly in favor of package (2) over package (3) because so long as carrots can be declined they should not defeat this power. Only one unbalanced package, (3), that of "carrots and no sticks," remains to be promoted or explained away; if it generates no counterproductive behavior and seems superior to package (2), then perhaps it should be hailed as an appropriate goal of law reform.

One might insist that the carrots contained in package (3), even though they are not large, would stimulate excessive precautions by potential rescuees. But it is difficult to imagine the excessive precautions that might be undertaken by swimmers or homeowners who knew that those who one day rescued them from water or fire would be entitled to a reward of, say, two hundred dollars. And if excessive precautions by such potential rescuees were imaginable, then it would even seem worthwhile for the state to absorb the cost of carrots in package (3) so that potential rescuees would not so fear the cost of being rescued. ${ }^{40}$ Alternatively, it might be argued that the carrots in package (3) would, as discussed earlier, generate the moral hazard of intermeddlers' creating the demand for their own services. But this argument should at most call for a modification of package (3) to contain "no sticks and skeleton"

\footnotetext{
to See infra text accompanying notes 131-32. Note that the government could tax the activity in question, such as hoat-owning, in order to finance these carrots.

"1 I use the term "skeleton" as opposed to say, "nominal," because the type of carrot to which I am referring is bare, hut not necessarily set at a small amount. A skeleton reward can be large so long as it is adequate only to cover expenses or the rescuer's inconvenience.
} 
carrots"- that is, carrots that will make rescue somewhat more attractive but not induce the strategic creation of emergencies. The legal right to reimbursement for the actual expense of a rescue would, of course, be just such a skeleton carrot. ${ }^{42}$ To be sure, such compensatory or skeleton carrots might be difficult and relatively expensive to administer. One might, therefore, expect to see some mix of package (3) with a balanced package depending on the valuation and administrative problems of particular settings.

One must always wonder whether carrots, skeleton or otherwise, should and would also be available to unsuccessful rescuers. I would expect such availability to be rare. In the first place, rescuers' claims would be hard to confirm or disprove. Second, it might seem wise to avoid the problem of someone beginning a rescue with little ambition and then turning back but claiming a reward. Finally, if rewards are privately financed, it might seem cruel to ask a grieving family or owner of recently destroyed property to pay for services that proved useless. The rewards received by successful rescuers could, of course, be adjusted so that, ex ante, potential rescuers are as motivated as they would be if they were to receive some carrots for all rescue attempts. In fact, most of the carrots described later on in this essay are available only to successful rescuers.

In sum, there are reasons to expect a rough balance between the rewards and penalties for rescues. Greater sticks must almost surely be accompanied by greater carrots, unless there is no activity-level effect at all, and large carrots may be counterproductive even when accompanied by sticks. But a shightly unbalanced package ("no sticks and skeleton carrots") seems, at least theoretically, to be superior to the balanced package of "no sticks and no carrots." That the latter package appears to describe the strategy expressed in American law is, therefore, somewhat puzzling. The discussion in Part II will suggest that American law is, in fact, much less puzzling than it first seems. ${ }^{43}$

\footnotetext{
42 These actual expenses may even include the value of one's time. The text ignores the moral hazard of an intermeddler's wanting to be a hero and creating an emergency to stage a rescue. This moral hazard seems fairly constant in size regardless of the legal rules affecting rescue.

${ }^{43}$ See infra text accompanying notes $51-81,184-95$. It is useful to note that this question of balance between rewards and penalties cannot simply be translated into a matter of counting and comparing instruments and goals. There are a fair number of available imstru-
} 


\section{Variety and Uniformity in the Treatment of Rescuers}

I argued in Part I that "sticks and (not too large) carrots" and "no sticks and skeleton carrots" would be sensible incentive packages for the purpose of promoting desirable rescues. I now turn to the incentives actually offered to potential rescuers and develop two points. First, American law may actually offer "no sticks and skeleton carrots" and, second, although different legal systems may provide dissimilar solutions to given problems-such as the promotion of desirable rescues-their treatments may be constrained by expectations about behavioral responses that may be quite alike in various societies. Indeed, I argue in this part that the balance between sticks and carrots, described in Part I as a product of behavioral considerations, is so durable that it is found not only in various areas of American law but also in civil law systems and in such ancient rules as those found in the Code of Hammurabi.

This second point is part of a larger positivist argument that I have developed elsewhere about "uniformity" and "variety" among legal systems. My suggestion is that different legal systems can be expected to display uniformity when a particularly necessary behavioral effect can be accomplished only with a certain rule. Variety, on the other hand, is to be expected either over a range in which rules do not greatly affect behavior or when reasonable people could disagree over which rule best accomplishes a desired effect. $^{44}$ Although this uniformity-variety thesis cannot be demonstrated in any deductive or inductive way, its plausibility is surely enhanced by demonstrations of its predictive power in different areas of the law. The discussion that follows thus not only shows that the incentive packages described as sensible in Part I are in fact those that are found in various legal systems but also lends

ments: rewards financed by rescuees, rewards financed by the government (or other third party), and sticks are three broad categories that have been discussed. But there is only one central goal-effecting socially desirable rescues-because there is, for example, no need to have people milling about on the heach if rescues are already taken care of in the calculus. Adding another goal, like the prevention of hazards (such as the drilling of holes in boats), hardly increases the number of goals beyond that of the available instruments. Generally speaking, we might expect a legal system to utilize all the availahle instruments in order to accomplish its goal(s) with greatest flexibility. And to some extent, American law, as we will see, does not ignore any available tool. But administrative difficulties and side effects-such as the danger that large carrots will in some settings lead to excessive precautions-suggest that all instruments will not be used in all settings.

"See Levmore, supra note 8, at 1-6. 
support to the larger argument about the uniformity and variety of legal rules.

\section{A. Incentives for Rescuers in American Law}

\section{Life Rescuers}

Medals and media attention aside, "no sticks and no carrots" is said to be the Anglo-American norm for those not contractually bound to undertake emergency rescue efforts. ${ }^{45}$ There are some well-known exceptions to this norm. Physicians and hospitals may be liable for ignoring emergencies and can certainly collect competitive carrots for any rescue efforts that they do undertake. ${ }^{46}$ Such exceptions are not at all surprising for, as discussed in Part I, "sticks and carrots" is in some settings quite a sensible package. In particular, it is not likely that serious moral hazard and excessive precaution problems would accompany the use of carrots for emergency professional medical services. A second well-known exception to the "no sticks and no carrots" rule is the statutory development of small sticks for nonrescue in some jurisdictions. Vermont and Minnesota have both legislated a "duty to rescue" when such rescue is riskless and have provided for a fine up to one hundred dollars for violations of this duty; Massachusetts and Rhode Island have legislated a duty to report a crime and have provided for sub-

${ }^{45}$ See generally R. Goff \& G. Jones, The Law of Restitution 263-67 (2d ed. 1978) (the common law denies restitution to one who intervenes on behalf of another); Feldbrugge, supra note 7, at 14 (Anglo-American legal system contains a notable exception to the general duty to offer aid to another where possible that is found in other legal systems); Gregory, supra note 6, at 23 (the common law has not enforced the moral duty to rescue); Weinrih, supra note 2, at 247 (no common law duty to rescue); Note, The Failure to Rescue: A Comparative Study, 52 Colum. L. Rev. 631 (1952) (no general duty to rescue in Anglo-American law).

18 Theoretically, physicians and hospitals can refuse to see patients just as a layperson can ignore stranded motorists. On the other hand, courts may be quick to decide that physicians and hospitals have undertaken to help a patient-and thus created a duty-and then wrongfully ahandoned the patient. If this abandonment, or negligence, is the cause of further injury, the patient will be ahle to recover. See cases collected in W. Wadlington, J. Waltz, \& R. Dworkin, Cases and Materials on Law and Medicine 470-72 (1980); Note, Must a Private Hospital Be a Good Samaritan?, 18 U. Fla. L. Rev. 475, 477-78 (1965).

Although there is some disagreement regarding the precise magnitude of recovery allowed physicians and hospitals who have rescued patients in emergencies, some recovery is clearly available. See cases collected in J. Dawson \& G. Palmer, Cases on Restitution 32-46 (2d ed. 1969). 
stantial penalties for failure to report. ${ }^{47}$ Inasmuch as the activitylevel effect of penalties is quite small, ${ }^{48}$ this development is hardly surprising. Still, I would expect these states to develop at least skeleton carrots to accompany these small sticks. Meanwhile, it is noteworthy that there have been no reported prosecutions under these statutes.

The most curious thing about American law-even outside of Vermont, Minnesota, Massachusetts, and Rhode Island-is the apparent absence of even skeleton carrots, for such carrots may promote desirable rescues at low cost. ${ }^{49}$ This curiosity might be dealt with in a number of ways. First, it could he argued that the costs of legal intervention must figure prominently in uniformity-variety predictions; American law may simply opt for little intervention..$^{50}$ Inasmuch as American law encourages physicians to provide emergency medical services and thus intervenes in at least some settings, a more sophisticated form of this argument would be that the costs of legal intervention may, in the eyes of American lawmakers, overcome whatever advantages carrots generate. Similarly, it might be argued that the rule does not much matter so that no level of carrots would be particularly surprising. Large carrots may generate large problems but skeleton carrots may offer such small incentives that variety ought to be expected between

47 Mass. Gen. Laws Ann. ch. 268, $\$ 40$ (West Supp. 1985) (duty to report, when no danger is thereby created, to appropriate official as soon as reasonably practicable when another person is victim of aggravated rape, rape, murder, manslaughter, or armed robbery; violator fined not less than $\$ 500$ nor more than $\$ 2500$ ); Minn. Stat. Ann. $\$ \S 604.05,609.02$ (West Supp. 1986); R.I. Gen. Laws §§ 11-37-3.1, 3.3 (Supp. 1985) (duty to report sexual assault (of another person) punishable by up to one-year imprisonment or fine not to exceed $\$ 500$ ); Vt. Stat. Ann. tit. 12, § 519 (1973). Until there are prosecutions to examine, I tbink it fair not to dwell on the penalties for failure to report, for given that they were passed following a widely publicized public sexual assault, see Prentice, Expanding the Duty to Rescue, 19 Suffolk U.L. Rev. 15, 33 (1985), they inay have been meant to be used as tools with which prosecutors can encourage members of a group to come forward and testify against wrongdoers or other group meunbers. They may even have been meant as a minimum (and easy to prove) charge for group crimes where major criminal convictions can be difficult to obtain. In any event, it is interesting to note that these duty-to-report statutes, in the style of Good Samaritan statutes and in the direction of symmetry, absolve one who reports from civil liability.

(s) Supra text preceding note 32 .

6) See supra text accompanying notes 40-42.

so Other legal systems may simply regard legal intervention as less costly. This is especially likely if private litigants in these systems have himited procedural options so that they are unable to impose substantial costs. 
"no carrots" and "skeleton carrots." But one need not choose between these explanations of American law, for the law and the curiosity just noted are generally misstated. In fact, American law does often provide at least skeleton carrots. The discussion in this section considers the ways in which American law rewards not only physicians but also other persons who voluntarily rescue life and property. In the sections that follow the analysis is extended to include other rescuers, including finders of lost property, salvors at sea, and "disclosers" of valuable information.

An important, if skeleton, carrot in American law consists of a promise to potential rescuers that they or their survivors will be able to recover for injuries suffered in a rescue attempt. It is not particularly interesting to find that such recovery is generally available from a negligent third party who creates the need for the rescue so long as the rescuer was not also a cause of the emergency. ${ }^{51}$ Courts may struggle a bit with causality doctrines, ${ }^{52}$ but it is rather clear that if without a rescue attempt of $\mathrm{A}$ by $\mathrm{B}, \mathrm{C}$ would be liable for injuries suffered by $A, C$ should and will be liable for injuries suffered by $B$ while undertaking a reasonable rescue. ${ }^{53}$ It is, however, much more interesting to note that a rescuer stands an excellent chance of recovering for his injuries when the victim's negligence created the need for rescue. ${ }^{54}$ It is difficult to see why the presence or absence of negligence by the rescuee himself should affect the rescuer's chances of recovery. The rescuer acts to save the rescuee the burden of his own injury-but this is so whether or not the emergency arose because of the rescuee's negligence. It is thus arguable that recovery by the rescuer in these cases not only represents an important subset of rescue cases in which carrots are available but also anticipates or opens up the possibility of recovery by rescuers in future cases in which there is

B1 See, e.g., Roanoke Hosp. Assoc. v. Hayes, 204 Va. 703, 133 S.E.2d 559 (1963); Andrews v. Appalachian Elec. Power Co., 192 Va. 150, 63 S.E.2d 750 (1951); Southern Ry. Co. v. Baptist, 114 Va. 723, 77 S.E. 477 (1913). For a case denying recovery where the rescuer was at least somewhat negligent, see Nelson v. Pendleton, 214 Va. 139, 198 S.E.2d 593 (1973).

${ }^{62}$ See Eckert v. Long Island R.R., 43 N.Y. 502 (1871).

${ }^{53}$ This may even be so when the rescuer has sought to save property rather than he. See W. Prosser \& W. Keeton, supra note $1, \S 44$, at 307-09.

s4 See e.g., Lynch v. Fisher, 34 So. 2d 513 (La. App. 1947); Brugh v. Bigelow, 310 Mich. 74, 16 N.W.2d 668 (1944); Talbert v. Talbert, 22 Misc. 2d 782, 199 N.Y.S.2d 212 (N.Y. Sup. Ct. 1960). But see Saylor v. Parsons, 122 Iowa 679, 98 N.W. 500 (1904) (a lone case denying recovery when only the victim was negligent). 
no negligence at all. It is possible that judges exploit the presence of negligence, however unconnected it is to arguments for recovery, as a means of protection against criticism that there will be no limit to their intermeddling. Over time, however, it may become easier to build on the many precedents in favor of recovery and argue that there is no reason why the absence of negligence should require a decision against the rescuer. Indeed, the dicta of the cases involving negligence by the rescuee himself have long contained the seeds of such evolution, for they speak of the rescuee as having created the need for rescue without insisting that the creation of the rescue-inviting situation was negligent..5

Another relevant development in American law may point to the development of sticks more than it does to that of carrots. Although the general rule of no sticks, or no duty to rescue, is solidly entrenched in most jurisdictions, many exceptions to this rule have been discovered in the form of "special relationships" out of which affirmative duties are said to arise. These exceptions have obviously not appeared in all jurisdictions but the overall appearance of these exceptions signals expansion. Although a finding of a special relationship normally precedes a finding of tort liability for nonrescue, it is not unreasonable to expect that carrots may grow next to these new sticks. After all, just as a physician's ability to recover for noncontractual emergency services seems to accompany the physician's duty to assist those in need of his services, perhaps because sticks alone would create an undesirable activity-level effect, so too might carrots accompany the sticks that are extended to "special relationships." The expanding set of exceptional special relationships to the "no duty" rule includes common carrier-passenger; ${ }^{58}$ innkeeper-guest; ${ }^{67}$ innkeeper-stranger (a duty to protect a stranger from injury by a guest); $;^{58}$ employer-employee; ${ }^{59}$ ship-crew-

ss See, e.g., Brugh v. Bigelow, 310 Mich. 74, 80-81, 16 N.W.2d 668, 671 (1944) (holding defendant who shouted for help from his overturned car liable for breach of duty not to make himself the object of rescue); Carney v. Buyea, 271 A.D. 338, 344, 65 N.Y.S.2d 902, 908-09 (1946) (holding that defendant who left her car out of gear on an incline breached legal duty not to create undue risk to herself).

${ }_{\text {Bb }}$ See Yu v. New York, New Haven, \& Hartford R.R. Co., 145 Conn. 451, 144 A.2d 56 (1958).

${ }^{87}$ See West v. Spratling, 204 Ala. 478, 86 So. 32 (1920) (duty of innkeeper to provide and maintain sufficient fire escapes for benefit of patrons).

so See Connolly v. Nicollet Hotel, 254 Minn. 373, 95 N.W.2d 657 (1959).

so See Rival v. Atchison, Topeka \& Santa Fe Ry., 62 N.M. 159, 306 P.2d 648 (1957). 
man; ${ }^{60}$ shopkeeper-business visitor; ${ }^{61}$ host-social guest; ${ }^{62}$ jailer-prisoner; ${ }^{63}$ school-pupil; ${ }^{64}$ drinking companions; ${ }^{66}$ landlord-trapped trespasser; ${ }^{68}$ safety engineer-laborer; ${ }^{67}$ physician-patient; ${ }^{68}$ psychologist-stranger (a duty to protect a stranger from harm at the hands of the psychologist's patient); ${ }^{60}$ manufacturer-consumer; ${ }^{70}$ landlord-tenant; ${ }^{71}$ parole board-stranger (a duty to protect strangers from a released prisoner); ${ }^{72}$ husband-wife; ${ }^{73}$ parent-child; ${ }^{74}$ and tavern keeper-patron. ${ }^{75}$ In all these settings it appears increasingly likely that duties will again be pronounced and that liability for nonrescue will follow.

The discussion in Part III of this article suggests a positive theory to explain the emergence of these special relationships and duties and also suggests the likely evolution of these duties and of rescue rules in the future. One feature of this list of special relationslips is, however, of immediate relevance. Apart from the familiar case of the plyysician rendering emergency services, four of the special relationships just cited do not involve preexisting relationships, although this is a concept that is often said to be related

${ }^{80}$ See Abbott v. United States Lines, Inc., 512 F.2d 118 (4th Cir. 1975).

${ }^{61}$ See L.S. Ayres \& Co. v. Hicks, 220 Ind. 86, 40 N.E.2d 334 (1942) (while shopkeeper may not be liable for failure to prevent unforeseeable injuries to invitee, he may be hable for failure to ameliorate the injuries via last clear chance doctrine).

${ }^{62}$ See Tubbs v. Argus, 140 Ind. App. 695, 225 N.E.2d 841 (1967) (driver may not invoke guest statute as a shield from liability for injuries not resulting from wanton and wilful acts where car was stopped and driver could have prevented further injuries).

63 See Farmer v. State, 224 Miss. 96, 79 So. 2d 528 (1955).

64 See Pirkle v. Oakdale Union Grammar School Dist., 40 Cal. 2d 207, 253 P.2d 1 (1953).

is See Farwell v. Keaton, 396 Mich. 281, 240 N.W.2d 217 (1976).

${ }^{68}$ See Pridgen v. Boston Hous. Auth., 364 Mass. 696, 308 N.E.2d 467 (1974).

67 See Caldwell v. Bechtel, Inc., 631 F.2d 989 (D.C. Cir. 1980).

68 See Davis v. Potter, 51 Idaho 81, 2 P.2d 318 (1931).

68 See Tarasoff v. Regents of Univ. of Cal., 17 Cal. 3d 425, 551 P.2d 334, 131 Cal. Rptr. 14 (1976).

${ }^{70}$ See MacPherson v. Buick Motor Co., 217 N.Y. 382.111 N.E. 1050 (1916).

71 See Kline v. 1500 Mass. Ave. Apartment Corp., 439 F.2d 477 (D.C. Cir. 1970).

${ }^{72}$ See Grimm v. Arizona Bd. of Pardons and Paroles, 115 Ariz. 260, 564 P.2d 1227 (1977).

73 See Territory v. Manton, 8 Mont. 95, 19 P. 387 (1888).

74 See Commonwealth v. Breth, 44 Pa. C. 56 (Clearfield County Ct. 1915).

${ }^{75}$ See McFarlin v. Hall, 127 Ariz. 220, 619 P.2d 729 (1980) (tavern owner may be held liable for injuries to plaintiff-patron froin acts of other patrons where tavern owner was negligent in not warning plaintiff of other patron's condition); see also cases cited in W. Prosser \& W. Keeton, supra note 1, § 56, at 376-77 nn.33-40 (discussing instances in which courts have justified the creation of an affirmitive duty upon the finding of "some special relation between the parties"). 
to liability for nonrescue. ${ }^{76}$ The liability of an innkeeper for not preventing injuries to strangers ${ }^{77}$ does not, for example, seem far from the question of liability for not rescuing one's neighbor. And, once again, carrots for rescuing one's neighbor seem related to sticks for not rescuing one's neighbor.

Finally, there is yet another subtle carrot (of unclear size) held out to potential rescuers by American law. While it is true that if $\mathrm{A}$ is injured while rescuing a nonnegligent $B, A$ is unlikly to be able to recover, what if $B$ or a relative of $B$ in a tender moment promises to pay A? Such promises are much more likely to be held enforceable than other promises for which there is no present or future consideration. ${ }^{78}$ I do not mean to insist that such promises will always be enforced. Indeed, good arguments can be advanced that A will only recover when it is B's estate that is sued after B has in fact made some payments as promised ${ }^{78}$ - so that enforceability may be an outgrowth of the law of trusts and estates more than contracts-or when it is plausible that A could have recov-

76 See supra, notes $48,57,59,62$ and accompanying text. A landlord and a trespasser on his property also can be said to involve no preexisting relationship. See supra note 66 .

${ }^{77}$ These are not cases in which the psychologist, for example, or his agent injure a patient who might be said to enjoy a preexisting relationship with the psychologist. Instead, the case concerns liability to a third person who had an unfortunate relationship with the patient. Similarly, the parole board, innkeeper, safety engineer, and landlord in the cases noted ahove were found to have duties not (merely) to the parties with whom they dealt, but to strangers.

7s See E. Farnsworth, Contracts § 2.8, at 55-59 (1982). It is not clear that promises would be enforced if the earlier rescue had been of the promisor's property rather than life or if the rescuer's injury were of loss of body or life and not of property alone. Indeed, I have chosen to concentrate on life rescue in this section not only because restitution for property rescue is something I have considered elsewhere, see Levmore, Explaining Restitution, 71 Va. L. Rev. 65 (1985), but also because the special relationships and other developments discussed in this section are probably not terrihly indicative of the likely treatment of property cases. A psychologist may be held hable for injury suffered by a stranger at the hands of a patient who might have been known to be dangerous, but one might hesitate to predict that the same legal result would be forthcoming in a case in which the patient carried out a threat to damage the stranger's property. I do think that the evolution of property rescue is likely to track that of life rescue. But because the developments in present law that most influence my argument may be limited to cases involving life rather than property, the discussion in this section is limited to life rescue.

79 The best known of these cases involve claims against the estates of promisors who, while alive, gave no indication that they wished to revoke their promises. See Webb v. McGowin, 27 Ala. App. 82, 168 So. 196 (1935), cert. denied, 232 Ala. 374, 168 So. 199 (1936); Estate of Hatten, 233 Wis. 199, 288 N.W. 278 (1940). The principle may thus have more to do with carrying out decedents' wishes than with subtly supplying carrots to rescuers. Both cases are discussed in E. Farnsworth, supra note 78, § 2.8, at 56-57. 
ered in tort from a negligent $B$ so that the promise is in return for A's forbearance from litigation. ${ }^{80}$ But it is noteworthy that the success of promisees such as $A$ is an exception to, rather than a wellexplained part of, contract law. Courts and commentators may insist that B's moral obhigation makes a difference, but inasmuch as a promisor can always be said to be morally obliged to keep his word and yet, as we know, gratutious promises are normally not enforceable, it seems most reasonable to look elsewhere for an explanation of A's success. It is, in short, possible that any special success of promisees such as A is best understood as part of the law of rescue. Although in some formal sense a potential rescuer does not face sticks and carrots, he is subject to penalties (and conceivably entitled to carrots) when a "special relationship" is found, he is able to collect when some negligent party created the need for rescue, and he may be able to collect on any promise that is made by one who benefits from his rescue efforts even though the promisor later seeks to repudiate his grant. Unfortunately, I have no way of knowing how often rescuees voluntarily reward their rescuers and how often rescuers sue on promises once made by their rescuees.

These developments and the preceding arguments lead one to believe that American law already grants some rewards to rescuers and may not be far from granting many more. I suspect that a rescuer who seeks to recover out-of-pocket expenses or other costs that are easily valued is more likely than other rescuers to secure recovery.$^{81}$ But it is difficult to assess the precise degree to which carrots are already available. If, for example, judges feel bound to the doctrinal steppingstone of negligence as a requirement for recovery by an injured rescuer, then it may take some time before sufficient precedents are created by more aggressive judges who overlook this apparent doctrinal requirement or create new "special relationships" that trigger both sticks and carrots.

so See Palmer v. Dehn, 29 Tenn. App. 597, 198 S.W.2d 827 (1946) (forebearance of suit sufficient consideration to support promise of compensation).

${ }^{81}$ It is arguable that professional rescuers, such as physicians and hospitals, have an easier time gaining carrots for their work because their services are often purchased and, therefore, relatively easy to value. See Landes \& Posner, supra note 19, at 109-10. This argument suggests that nonprofessional rescuers migbt be most successful when bringing claims for (easily valued) out-of-pocket expenses. 


\section{Finders and Disclosers}

One who stumbles across lost property or useful information and one who invests in discovering such property or information are similar in important ways to more recognizable potential rescuers who come across victims in distress or more purposefully set out on rescue missions. There are, of course, many other actors that are encouraged by sticks and carrots-soldiers and taxpayers come quickly to mind-but because the incentives offered these actors do not normally generate moral hazard problems, activity-level effects, and excessive precaution-taking, I think it is fair to say that it is finders and disclosers who are sufficiently like more familiar rescuers to merit parallel discussion.

Under American law a finder is perfectly free to pass by and ignore the property he sights; ${ }^{82}$ in this sense there are no sticks. To be sure, a finder must not simply appropriate for himself property that he discovers, much as one must not swim out to a drowning stranger who is calling for help and strike him on the head. There is, however, no legal obligation to secure and return lost property ${ }^{83}$ just as there is no obligation under American law to go out and save a drowning swimmer. ${ }^{84}$ If a finder does affirmatively take charge of lost property and return it or seek out its owner, then a variety of carrots are available. First, any reasonable expenses incurred in caring for the lost property will usually be recoverable from the owner, or implied bailor. ${ }^{85}$ The finder, or involuntary bailee, may be held liable for losses his negligence causes but such negligence is not quickly imputed. ${ }^{86} \mathrm{He}$ is given loose rein to sell the property and hold the proceeds for the owner's arrival when

82 Not only are there no statutory provisions or judicial decisions requiring someone to "find" lost property, R. Brown, The Law of Personal Property $\S 3.5$, at 30 (3d ed. 1975), but also I know of no case in which a plaintiff even sought to have such a duty imposed. I do not think that those who have lost property have been unwise in failing to bring such claims.

ss Id.

84 W. Prosser \& W. Keeton, supra note $1, \S 56$, at 378.

${ }^{85}$ See Chase v. Corcoran, 106 Mass. 286 (1871); R. Brown, supra note 82, § 3.5, at 30-31. But see Watts v. Ward, 1 Or. 86 (1854) (finder unable to recover expense of returning lost horses to owmer). Some states now have statutes requiring the compensation of finders for their expenses. See, e.g., Or. Rev. Stat. $\$ 98.025$ (1984) ("all the costs and charges incurred in the finding, giving of notice, care and custody"); Wis. Stat. Ann. $\$ 170.09$ (West 1974) ("all the costs and charges ... including a reasonable compensation to the finder for his trouble").

ss See $R$. Brown, supra note $82, \S 12.2$, at 322 . 
the ongoing expenses of care seem likely to overwhelm the value of the property, ${ }^{87}$ and, unlike other bailees, he will not be held liable for nonnegligent misdelivery. ${ }^{88}$ Second, and more important, with the exception of some rare cases in which there is a terrific moral hazard that the "finder" has simply taken possession of another's goods, ${ }^{89}$ finders are allowed to keep property that is unclaimed after the passage of some specified amount of time. ${ }^{90}$ The finder thus gains title superior to all the world but for the original owner-and eventually even the original owner loses out because of a statute of limitations. The finder's most important carrot is, therefore, the expected value of the owner's inability or unwillingness to claim the lost property despite any rules that require the finder to advertise the find, ${ }^{91}$ discounted by the possibility that a claim by the owner of the locus in quo will be treated sympathetically ${ }^{92}$ and by the possibility that the property will be regarded as legally misplaced rather than lost. ${ }^{93}$ Third, the finder may hope that the property will sometimes be treated by the law as abandoned rather than lost or misplaced and, again, that no owner of the locus in quo will successfully claim the property. In these circumstances the finder will gain title to the property regardless of whether its former owner materializes. ${ }^{94}$ Fourth, a finder may hope that the

87 Thus, a landlord is often allowed to sell goods left behind by a tenant. Id. $\S 12.1$, at 320-21 \& n.4.

ss See id. § 21.3, at 327-28.

82 In Iowa, found vessels, rafts, logs, or lumber that are unclaimed and exceed twenty dollars in value become the property of the county (after expenses, such as that of publication are paid). Iowa Code Ann. $\$ \$ 644.1,644.4$ (West Supp. 1986). Inasmuch as other unclaimed lost property becomes the property of the finder, it seems that the point is to decrease the moral hazard of "finding" lost property that is afloat and really under the control (but not surveillance) of its owner. The same is true of "treasure troves" (caches of gold and silver of unknown origin) in English law, where a similar moral hazard may exist. R. Brown, supra note $82, \S 3.3$. Wisconsin does, however, appear to require all finders of (eventually) unclaimed property to share their luck with the government. Wis. Stat. Ann. $\S 170.10$ (West 1974). Such a rule might be regarded as an income tax on receipts that are likely to go unreported (if only because finders might not realize their reporting obligations) in both the state (if any) and federal tax systems.

90 See, e.g., Mont. Code Ann. § 70-5-206 (1985).

92 Montana has particularly elaborate requirements. Mont. Code Ann. $\S \S 70-5-203$ to -206 (1985) (requiring appearance of finder before justice of the peace, swearmg of affidavit, appraisal, recordation, notice, and advertisement).

${ }^{22}$ See $\mathrm{R}$. Brown, supra note $82, \S 3.2$, at 26 .

s3 Id. $\S 3.4$, at $29-30$.

94 Id. \& 3.1, at 25 n.1. 
owner will provide a reward for the return of his property, or the finder may know of such a reward and simply expect (quite correctly) that such a promise will be enforced. ${ }^{95}$ Fifth, and finally, a finder may be able to extract a reward from the owner who reclaims his property because such a reward is provided by statute. Iowa, in particular, provides for a ten percent commission in addition to the expenses incurred for one who finds and takes up boats, money, bank notes, lost goods, and "other things."

That these carrots are, ex ante at least, relatively substantial and yet not balanced by accompanying sticks is quite explicable. Here, it is an analysis of the behavioral effects of carrots and sticks more than an application of the uniformity-variety thesis that allows one to predict the range of legal rules. Two minor problems might be generated by these carrots. It is possible that owners will take excessive precautions against losing property because their liabihty to finders may seem great in light of the likelihood that somebody will return lost property even if no reward is available. It is also possible that potential finders will actually cause losses and then hide the items that they find from their true owners. The notion that "misplaced," as opposed to lost, property remains in the custody of the owner of the locus in quo and not of the finder (who is also then unable to claim a reward offered for finding) ${ }^{97}$ appears to respond to this concern. The behavior of someone who "finds" property that has been intentionally placed down by another is simply suspect, for it is too easy to "admire" a coat or jewel set down by its owner and then, if opportunity strikes and the law rewards, claim to have found it. The owner who traces his steps will also have an easier time locating his property if it remains where the owner has actually been.

But a more important moral hazard dominates any consideration of carrots: Finders may simply appropriate their discoveries for themselves and not publicize their finds. Lawmakers must thus balance the degree to which moral behavior, altruism, probabalistic rewards, and the fear of sticks for affirmative misdeeds such as

os See Wentworth v. Day, 44 Mass. 352 (1841); R. Brown, supra note 82, § 3.5, at 31. The finder may, however, need to have learned of the reward before completing his performance. See E. Farnsworth, supra note $78, \S 2.10$, at 65 .

${ }^{96}$ Iowa Code Ann. $\S 644.13$ (West 1979).

${ }^{27}$ See R. Brown, supra note $82, \S 3.4$. 
hiding the find or causing the loss itself will offset the finder's selfinterest in simply taking or ignoring the property. Put differently, since affirmatively misbehaving finders run a low chance of detection and prosecution, their behavior may be thought best modified by rewards and penalties rather than by penalties alone. This policy alternative is surely made more feasible by the fact that the law's target is identifiable-it would be easier to give carrots to finders than to give carrots to all those who do not shoplift, for example-and more attractive by the fact that the rewards to finders need not be financed by the state itself. The state could claim for itself property that no owner claims and in this sense the state-by allowing finders to keep unclaimed property-does finance the most important carrots, but it is easy to imagine that lawmakers regard as costless the rule that finders gain title when original owners fail to appear. In short, "no sticks and no carrots" would not be a terribly surprising package because lawmakers might think that the moral hazard that potential "finders" will cause losses or just not announce their finds combined with the problem of excessive precautions by owners overcomes the advantages of carrots both in encouraging finds and in discouraging postfind misbehavior. Yet "carrots and no sticks" is surely no less surprising; reasonable people could disagree over the magnitudes of the various behavioral effects, and experience or experimental data seem unlikely to clarify the choices. ${ }^{98}$ In sum, an analysis of the law pertaining to finders does not demonstrate a perfectly durable balance between rewards and penalties. Instead, it demonstrates the usefulness of beginning the inquiry with such a balance in mind and then understanding the deviations from it as relating to particular circumstances. The "carrots and no sticks" pattern found in the law of finders is surely responsive to the moral hazard of finders' taking and not reporting their finds.

Disclosers are best compared with finders in a way that anticipates the analysis in Part III. It is difficult, as a law enforcemant matter, to identify potential finders who simply ignore lost property (as opposed to misbehaving finders who convert the property for their own use) but easy to single out persons who do not dis-

${ }^{88}$ It is difficult to collect data on the ignoring of obviously lost property and on the pocketing of sucb property. The effect of a reward may be to encourage finders to report that which they have gathered in. 
close material information when bargaining, if only because those who bargain or transact are a subset of the larger group of those who have information. Hundreds of people in a neighborhood may know that termites have infested the area, but if the law wishes for a buyer to bargain for a home with this information in mind, it is much easier to impose a duty on the seller rather than on all neighbors with information.

The familiar problem with sticks in this context is that investment in discovering information may be discouraged if the investor is not permitted to profit from his information. Inasmuch as I have elsewhere expressed my own positive view that the law generally protects those investors by not requiring disclosure except in those circumstances, such as termite infestations and situations in which the uninformed party reveals idiosyncratic concerns by asking specific questions, in which non-disclosure allows net losses to occur, ${ }^{99}$ I will not review it or the intricacies of the substantive law here. I think a fair summary of the law is that "rare sticks and negotiated carrots" are available to potential disclosers of information. Sticks are imposed only when the cost of nondisclosure, such as continued termite damage, exceeds the social loss that will result from denying some "investors" the full value of their information. Homeowners, for example, have a fair incentive to inspect regularly for termites, especially if buyers will as a matter of course ask specifically to inspect. Similarly, managers of business enterprises have good reason to explore for corporate opportunities, even if they must then abstain from or reveal information when trading shares of the enterprise. On the other hand, if sticks were instead imposed for all nondisclosure by corporate insiders, so that all who traded ignorantly on the stock exchange could recover if material information had been withheld (by insiders who did not themselves trade), then surely there would be much less exploration in tbe first place. ${ }^{100}$

It may seem at first that these "rare sticks" could only be accompanied by "no carrots." In the corporate sphere, a non-insider

\footnotetext{
99 Levmore, Securities and Secrets: Insider Trading and the Law of Contracts, 68 Va. L. Rev. 117, 133-42 (1982).

${ }^{100}$ This stick for nondisclosure is especially interesting because without it one might be tempted to suggest that sticks are used only when life (as opposed to property) rescue is at stake.
} 
who develops information need not disclose such information when he trades with a stranger (no sticks) and it is hard to see how the law could possibly reward him for generously revealing information. Valuation, moral hazard, and precaution problems abound. But in some sense the discloser can extract carrots by contracting for them with the party with whom he trades. If he has developed a reputation as someone who often possesses useful information, then a stranger may pay him for his whispers. And, in general, it may be possible to give unrevealing but convincing clues so that a stranger will believe that valuable information is available for purchase. In many settings it will be possible to package information with products or services so that carrots can be bargained for in return for information. An automobile mechanic need not tell me that he can hear that my carburetor needs adjusting (sticks would discourage investment in his training), but if I regularly buy gasoline at his service station he may make a practice of so informing me. These "negotiated carrots" encourage the production of useful information and do not normally create moral hazard problems. When such problems may be generated, as when corporate insiders may intentionally cause financial losses in order to profit personally from inside information, sticks (for "tipping," for example) are available to combat the hazard. In contrast, the law will not enforce "bargains" for carrots made between potential rescuers and drowning victims. ${ }^{101}$ And although anticipatory contracts made long in advance between these parties may well be enforced, affirmative misbehavior (such as setting fire to a neighbor's house after he agrees to pay for a rescue) is severely penalized, and the parties themselves know to be wary of the moral hazard created by these contracts. ${ }^{102}$ I may, for example, contract with a reliable friend for some future activity in a way that I would not contract with a stranger.

101 The statement in the text is not based on real case authority for there appears to be none. Still, it is almost inconceivable that a profitable rescue contract, "bargained" for during an emergency, would be enforced. Courts would surely put terms like "duress" and "public policy" to good use. A contract made under duress is voidable at the insistence of the victim. See E. Farnsworth, supra note $78, \S \S 4.9,4.16-4.20$ (discussing the requirements for a showing of duress).

${ }^{102} \mathrm{~A}$ and $\mathrm{B}$ may agree to rescue one another in the event of a future fire. But $\mathrm{A}$ is unlikely to agree with stranger $C$ that if $A$ 's house catches fire $C$ will save $A$ and earn a good deal of money. C, after all, may be tempted by these terms to start a fire. 
"Rare sticks and some negotiated carrots" is thus quite explicable, given the now familiar behavioral effects involved, but by no means entirely predictable or stable. Variety may extend to packages with a few more or a few less sticks, for example, but it is surely unlikely that a legal system will offer "sticks and (allow) no negotiated carrots" or "no sticks and large carrots" because such packages would, respectively, stifle the production of desirable information and generate serious moral hazard and excessive precaution problems.

\section{Admiralty Law}

The set of incentives available under American law to salvors at sea is arguably a bit less consistent with the analysis begun in Part I than is the treatment of finders, disclosers, and rescuers on shore. The general rule for property salvage in admiralty law is "carrots and no sticks;" successful salvors are compensated and yet one need not attempt the rescue of a sinking ship any more than one must volunteer to fight fires on land. ${ }^{103}$ Commentators seem to agree that compensation for salvage, while somewhat arbitrarily determined, does more than reimburse salvors for their expenses and may be generous enough, in fact, just to succeed in promoting a competitive market in such rescues. ${ }^{104}$ So long as salvage awards are not too great, it is possible that the unbalanced package just described does not contradict the analysis in Part I. The absence of sticks ensures that there will be no activity-level effect and the presence of moderate carrots encourages rescue without encouraging excessive precautions. My impression is that most seagoing vessels are usually guarded at all hours so that there is not much of a moral hazard problem generated by the offer of carrots to salvors. To be sure, there is quite a history of land-based pirates' sending out false signals in order to induce ships to take courses that cause them to crash on rocks. But given that these pirates have sought to help themselves to the spoils rather than to collect lawful salvage claims, it is arguable that carrots have little to do with the criminal

${ }^{103}$ See G. Gilmore \& C. Black, The Law of Admiralty $\S \S 8.1-8.4$ (2d ed. 1975).

104 See Landes \& Posner, supra note 19, at 100-05 (the goal of salvage law is to reconstruct the contract that the parties would have made ex ante if a competitive market transaction had heen available). 
behavior just described. ${ }^{105}$ In any event, sticks seem inappropriate for potential salvors, for there are few passers-by at sea and it is hard to see how, for instance, everyone in Boston could be penalized for nonrescue if a radio station announced that a ship in Boston Harbor was in distress and needed help. The activity at issue is not beach strolling or sudden heroism but long term investment in tugboats and other salvage equipment. Carrots that provide a competitive rate of return seem both necessary and sufficient to promote this end. Sticks are, of course, necessary to deter criminal activities such as piracy; but the magnitude of these sticks and the enforcement strategies that accompany them are topics that can be separated from the questions of the ideal magnitudes of sticks and carrots held out to potential rescuers.

If the moral hazard problem accompanying these carrots is a serious one, perhaps because potential salvors collude with crew members, then the carrots for salvors could be smaller, if not downright skeleton-that is, simple reimbursement for expenses-by awarding smaller carrots for all rescue efforts rather than larger ones only for successful rescues. But such a scheme is almost surely more trouble than it is worth, for unemployed salvors might flock to the scene of a hopeless disaster and insist later that they had genuinely tried to save the day and should all be compensated. The problem may be no more than a factfinding nightmare ${ }^{108}$ in which errors are costly because they generate excessive precautions by owners. But this is probably enough to lead one to expect, from the perspective of the uniformity-variety theme, that "no sticks and skeleton carrots (to all who attempt rescue)" will not be found interchangeable with "carrots and no sticks."

The "carrots and no sticks" rule is abandoned in the law's treatment of pure life salvage, when the salvor saves human life and is unable to attach his claim to one for property salvage. When both life and property are saved in one incident (but even, or especially if, by different salvors) the life salvor does recover, so there is little

${ }^{105}$ Criminals who sought salvage awards would increase the chance of their own identification and conviction. It is, therefore, hard to imagine that salvage rewards had anything to do with piracy.

${ }^{108}$ See Landes \& Posner, supra noto 19, at 104 (noting that it is easier to monitor outputs). 
chance that a strategic salvor will ignore life and save property. ${ }^{107}$ When life alone is at stake, however, no carrots are offered. Moreover, there is both a commonly accepted moral duty and a penaltyreinforced statutory duty "to render assistance to every person who is found at sea in danger of being lost."108 Variety thus seems to appear just where it might have been expected because this "sticks and no carrots" package can be viewed as an alternative metlod of encouraging certain behavior. The discussion in Part I suggested that this sort of package was attractive because the denial of carrots eliminates problems of moral hazard and excessive precautions (although it is questionable whether these problems are present in the admiralty context). Carrots may also be inferior to sticks, especially in this setting, if the potential rescuers are concerned that rescuees will be judgment proof and if the state lias not promised to step in and pay deserving rescuers in such circumstances. Moreover, the presence of sticks was said to generate an activity-level problem only where tliere were indentifiable rescue spots that potentially liable parties might avoid. It is arguable that there is an especially insignificant activity-level problem generated by sticks for nonrescue at sea. To the extent that familiar sea lanes present indentifiable rescue spots, potential rescuers will be in these lanes as a matter of course-so that no substantial detour is required to accomplish a rescue-and the advantages of using charted sea lanes almost surely outweigh the cost of rescuing hives that happen to be in need of rescue in these very lanes.

Even if the "sticks and no carrots" package does create an unfortunate activity-level effect, there is little room for variety. It lias, for example, been alleged that vessels liave steered clear of normal sea lanes in the South Clina Sea to avoid coming across "boat people" in great need of rescue. ${ }^{109}$ This activity-level effect may be

${ }^{107}$ For the detailed rules, see G. Gilmore \& C. Black, supra note 103 , § 8.12; see also Landes \& Posner, supra note 19 , at $105 \&$ n.48 (noting that law must be careful not to increase opportunity costs of altruistic life-saving and citing fascinating and supporting cases).

${ }^{108}$ See generally G. Gilmore \& C. Black, supra note 103, $\S \S 8.1$, at 534 n.7, 8.12 (discussing duty to rescue in American admiralty law).

${ }^{100}$ See, e.g., N.Y. Tines, July 15, 1979, at 1, col. 3 (reporting on allegations that Japanese vessels avoided refugees). The overwhelming impression one gets from reading other newspaper articles in this period supports the contrary conclusion discussed in the text; potential rescuers will, as a matter of course, be in the sea lanes to which victims will ain so that actual detour costs of such rescues will be low. 
quite striking because people in need of rescuers would surely try to manuever their inadequate boats to spots where rescue would be most likely. But even if the "sticks and no carrots" package generates this behavior it is hardly the case that "carrots and no sticks" would be superior. First, these victims are not in the financial position to guarantee the carrots. Second, in other circumstances not involving boat people victims in need of rescue at sea must often have been aboard other vessels whose owners will be liable in tort (for the negligent navigation of the vessel, for example) for all injuries suffered. If the owners of these vessels must because of subrogation arguments pay life salvage awards, then it is possible that other tort claimants will simply go uncompensated because total liability is as a practical matter often limited to the value of the vessel and of insurance policies carried. Carrots may thus accoinplish questionable redistributions and encourage one form of desirable behavior only at the expense of another. ${ }^{110}$ Third, there is no reason to think that penalties decrease the total number of rescues; some ships may, at a minor cost, avoid the usual sea lanes, others will continue as before, but it is hard to imagine that fewer ships will venture out to sea or that the withdrawal of penalties will suddenly cause more ships to undertake the rescue of persons they encounter.

"Sticks and no carrots" may thus be superior to "carrots and no sticks" in the context of life salvage. Of course, as noted earlier, carrots could be guaranteed by a government or by a rehef organization so that "sticks and carrots" would be even better than "sticks and no carrots." These carrots must not be too rewarding and there must be some policing of salvage claims because there is the moral hazard of "salvors" colluding with "victims," but it is likely that some positive level of carrots will do more good than harm. Interestingly, English law does provide for a special fund for life salvors. ${ }^{111}$ In short, it would not be suprising to see a move towards "sticks and carrots," but the prevalence of "sticks and no carrots" for pure life salvage is especially interesting because it displaces the "carrots and no sticks" norm in salvage situations precisely in the circumstances in which sticks are feasible (or at least

110 The point is discussed in Friedell, Compensation and Reward for Saving Life at Sea, 77 Mich. L. Rev. 1218, 1254-55 \& n.131 (1979).

111 Id. at 1232. 
not completely unworkable) and in which carrots are either unbelievable, ultimately financed only by other sympathetic victims, or the cause of a potential moral hazard. This displacement is thus quite consistent with the notion that variety among legal rules will be found where such variety does not lead to terribly different or destructive behavior.

The preceding analysis may, however, be entirely premature. There is some reason to think that the traditional "no carrots" rule for life salvage has been slowly eroded and that recovery by pure life salvors is increasingly likely. ${ }^{112}$ Such a development, combined with the obligation to save life at sea, would be an obvious step towards the symmetry introduced in Part I and demonstrated in this Part. It may, moreover, signify that at the present time carrots are thought not likely to generate moral hazard problems and not too frequently to be at the expense of sympathetic tort claimants. But there is no reason not to expect variety over time and across jurisdictions between "sticks and carrots" and "sticks and no carrots." There is, on the other hand, every reason to think that uniformity will extend so far as to hold off a "no sticks" approach because, as discussed earlier, it is hard to see how such sticks could be counterproductive when minor detours at sea to rescue lives are concerned. On the other hand, "no sticks" is quite predictable in the context of property or property and life salvage, because it is in this context that investment in equipment and prepositioning are normally required. Such investment and prepositioning are precisely the sort of activities that might be discouraged by sticks for nonrescue.

\section{B. European Civil Law Systems}

The balance between the sticks and carrots offered to potential rescuers is hardly unique to American law. Although its durability is perhaps increasingly impressive the furtlier one looks from American law-for a society's legal rules then appear predictable

112 See id. at 1271-87. The discussion in this article excludes the possibility that the Coast Guard and other "public rescuers" might collect for their successful (or all) efforts. Essentially, this is best seen as a contractual question. My taxes support the local fire department, but the government could presumably declare that free fire protection is only available to nonnegligent homeowners. Such a government's success in recovering for noncontractual emergency services would then depend on many of the considerations suggested earlier. 
even without much knowledge of its cultural norms and sociological features-it is useful to move away from American law rather slowly and to consider first modern European law. ${ }^{113}$

The most striking aspect of the treatment of rescue in modern European civil law systems is that sticks are often available for and applied to nonrescuers. These sticks usually take the form of criminal penalties, consisting of fines, imprisonment, or both, and may be accompanied or extended by exposure to civil liability. ${ }^{114}$ French law, for example, provides a fine and jail sentence for someone who does not undertake a riskless rescue of an endangered person. ${ }^{115}$ The statute applies only when a person-and not property alone-is in danger. ${ }^{116}$ The nonrescuer is also subject to civil liability, and such liability is triggered by both intentional and negligent omissions. ${ }^{117}$

In practice, French law provides skeleton carrots to go along with the sticks just described. If a rescuer has suffered damage or incurred expenses, recovery will usually be possible from the rescuee who will be said to have impliedly contracted for the rescue effort, from a tortfeasor who will be said to have caused the rescue attempt, from the rescuee or his insurer who may be identified as unjustly enriched, or simply from the rescuee by an action of negotiorum gestio, under which one who acts for the benefit of someone who is unable to take care of himself is able to recover, especially when the unilaterally created "agency" turns out to be useful to the principal. ${ }^{118}$ Inasmuch as all but the very first of these four routes to recovery by the rescuer promise rewards suffi-

${ }^{113}$ The text does not focus on the treatment of rescue in Roman law. It appears that although Roman jurists, through the labels of actio utilis and actio in factum, sought to sanction some wrongful omissions, there was no clear move towards an obligation to rescue unrelated persons or property. See B. Nicholas, An Introduction to Roman Law 220-21 (1962). Nevertheless, one might recover for the expenses of such a rescue, within the confines of the principle of negotiorum gestio. Id. at 231-33. I have avoided more discussion of Roman law precisely because there is such limited evidence of its practices and rules relating to rescue and nonrescue.

${ }^{114}$ See Rudzinski, supra note 7, at 108-15.

115 See generally Tunc, The Volunteer and the Good Samaritan, in The Good Samaritan and the Law, supra note 5, at 43, 45-48 (discussing article 63 of the French Penal Code and its provision that one who abstains from a riskless rescue incurs a pimishment of three months to five years in jail in addition to a fine).

11 Id. at 47.

117 Id. at 49-50 (civil liability for negligent omissions even when no crime).

118 Id. at $52-54$ \& n.17. 
cient only to reimburse the rescuer for expenses, the package provided by French law is best described as "sticks and skeleton carrots." Unless factfinding errors are great and are biased in the rescuer's favor, these carrots are surely insufficient to generate moral hazard problems and most unlikely to lead to excessive precaution by potential rescuees. Moreover, these carrots can be declined by rescuers who wish no material rewards. Although the sticks offered in French law could conceivably lead to an undesirable activity-level effect if potential rescue spots are identifiable, reasonable people can disagree whether French-style "sticks and skeleton carrots" or "no sticks and skeleton carrots" is preferable. ${ }^{118}$ The point is that the "sticks and skeleton carrots" package offered in French law is an illustration of the sort of variety one might expect after considering the likely behavioral effects of penalties and rewards of various size. ${ }^{120}$ "Sticks and no carrots" would, in contrast, be quite a surprising package, for the behavioral effect of not reimbursing the expenses of rescue (that is, the denial of skeleton carrots) and the activity-level effect of penalties, however mild, would together be enough to convince lawmakers that such a package would discourage rather than encourage desirable rescues.

Other European legal systems also provide "sticks and skeleton carrots." Nonrescue is a criminal offense in most of Europe; penalties range from a fine only to imprisonment of up to five years and fine. ${ }^{121}$ In some systems the penalty is increased if the victim dies, in one legal system there is no penalty unless death actually results from the failure to rescue, and in at least one legal system the nonrescuer is punishable even if, because of fortunate subsequent events, no harm at all befalls the victim. ${ }^{122}$ About one half of the countries with sticks for nonrescue limit their applicability to situ-

\footnotetext{
119 There could also be disagreement over whether tbe carrots should be more than skeleton in order to better overcome the activity-level effect of the sticks.

${ }^{120}$ The text does not mean to suggest that this package is predictable, but rather that it is one of a group that might have been expected. Again, "sticks and carrots" would also have been possible.

121 See Rudzinski, supra note 7, at 110 (reporting penalties that "range from a fine only (Turkey) through a fine or simple detention (Denmark), fine or imprisonment (Norway), prison or fine (Germany), correctional labor or social censure or applying measures of social influence (Russia), arrest or fine (Italy), detention and fine (Netherlands), imprisonment or fine or both (France, Belgium), imprisonment or arrest (Poland), to deprivation of liberty only (Rumania, Czechoslovakia, Hungary)" (footnote omitted)).
}

122 Id. at 108-10. 
ations involving sudden and imminent danger to human life, so that there is no liability for failing to rescue someone from nonfatal injury. ${ }^{123}$ In a few European countries there is a clear private right of action against the nonrescuer; it is uncertain to what extent such civil suits would be successful in other countries with statutes tbat impose criminal sanctions for nonrescue but are silent regarding civil liability. ${ }^{124}$ In some countries the potential for criminal liability is limited to persons who actually witness or find a victim in distress, ${ }^{125}$ in at least one there is criminal liability for nonrescue even if there is serious risk involved in a rescue attempt, ${ }^{126}$ and in some, all risk can be avoided by obtaining the help of professionals or by informing the proper authorities of the need for assistance. ${ }^{127}$

It appears that the very modest carrots offered to rescuers in French law are also available in other European systems. German courts, for example, have exphicitly extended the implied agency notion of negotiorum gestio to allow the rescuer not only to recover the expenses of "managing the affairs" (the rescue) of the "principal" in need of assistance but also to recover for injuries suffered as a result of the rescue effort. ${ }^{128}$ Whether courts in other countries use this means of granting recovery, or instead, extend the notion of general average contribution in admiralty law to emergencies on land ${ }^{129}$ or simply follow explicit legislative directions to compensate rescuers, ${ }^{130}$ there is every reason to think that "sticks and at least skeleton carrots" is the rule in a great many European legal systems.

The balance I have suggested between sticks and carrots would appear even more durable-and the uniformity-variety thesis itself especially attractive-if some legal system offered carrots (but not terribly unbalanced ones) that were financed by the state. Reasonable lawmakers might, after all, think that excessive precautions

${ }^{123}$ Id. at 96 (Netherlands, Norway, Denmark, Poland, Czechoslovakia, and Germany limit duty to situations involving danger to human life).

124 See id. at 112-15.

125 Id. at 101.

${ }^{128}$ Id. at 105-06 (only danger to life of rescuer relieves responsibility in Rumania).

${ }^{227}$ Id. at 108 (in Italy, Turkey, Rumania, and Soviet Union law formulates alternative duty to render help or inform immediately the proper authority).

${ }^{128}$ See id. at 115 .

129 Id. at 115-16.

${ }^{130}$ Id. at 116 (noting Austrian, Polish, and Czech legislation). 
by potential victims constitute a more serious problem than the cost of carrots and the special moral hazard created by tempting "victims" to collude with "rescuers" in order for the latter to collect their carrots from the fisc. Remarkably, Austrian law appears to provide just such carrots: a cash award from a public fund is available by law to someone who risks his life and saves another from imminent death. ${ }^{131}$ It seems, however, that in practice the awards are quite discretionary, more like occasional medals than calculated carrots, and sufficiently unfamiliar that few potential rescuers could possibly be motivated by their existence. ${ }^{132}$

\section{The Treatment of Rescuers in Primitive Laws}

The analytic tools developed in this article are even useful in explaining the carrots and sticks held out to potential rescuers in civilizations far removed from our own. Although there is little, if anything, in any code of laws of which I am aware that contradicts the thesis developed in this essay, there is also not a great deal in many ancient or primitive legal systems that supports my thesis, for in many cases there is simply very little information regarding the treatment, if any, of finders, salvors, and other rescuers. There are, however, significant and fascinating clues about the law of rescue in three primitive legal systems. In this section I report the rules that contain these clues and consider the ways in which the now-familiar balance between sticks and carrots may or may not be reflected in these rules. I begin with the Code of Hammurabi, thought to have been promulgated by the ruler of Babylon between the twenty-second and eighteenth centuries B.C., continue with the laws of the ancient Hittites, thought to have been codified between the fifteenth and thirteenth centuries B.C. in a civilization located in modern-day Turkey and Syria, and conclude with the customary laws of various Mongolian tribes, thought to have emerged in the thirteenth century and evolved through the seventeenth and eighteenth centuries when many of these customs were codified. ${ }^{133}$ Although these primitive provisions may at first seem

\footnotetext{
131 Id. at 117.

${ }^{132}$ Interview with Herhert Hausmaninger, Professor, University of Vienna Law School (Aug. 7, 1985).

${ }^{133}$ See G. Driver \& J. Miles, 1 The Babylonian Laws 3, 34 (1952); E. Neufeld, The Hittite Laws 70 (1951); V. Riasanaovsky, Customary Law of the Mongol Tribes 5-17, 20-21, 30, 39-
} 
quite unrelated to the very real questions posed by contemporary rescue law, I warrant that the trusting reader will find these old rules remarkable and informative. The problem of encouraging desirable rescues, and of creating affirmative obligations in general, is, as will soon be clear, hardly a new one. Unfortunately, the material that survives from primitive legal systems is in a form that requires careful (some would say impossible) textual exegesis. The discussion that follows thus does not simply list various sticks and carrots but instead explains why I think it fair to conclude that certain incentives were offered to potential rescuers in these ancient or remote civilizations.

\section{Hammurabi's Code}

The Code of Hammurabi contains the earliest known rules that deal with the question of affirmative obligations. ${ }^{134}$ After providing for serious punishment for one who "has harboured in his house" a slave he knows to be a fugitive, ${ }^{135}$ the Code provides in section 17 that: "If a man has seized in the field a fugitive slave, male or female, and has brought him back to his lord, the owner of the slave shall pay him two shekels of silver." There is no provision that affirmatively requires the capture and return of a fugitive slave or of any other property; sticks were presumably limited to active misdeeds such as the harboring-as opposed to the overlooking-of a fugitive. The carrot provided in section 17 is, however, of substantial size; two shekels is, for example, the compensation sug-

40, 52 (1981).

234 The laws of the city-state of Eshnunna are thought to be the only older (surviving) system of laws, and they contain no provisions that can safely be interpreted as dealing with omissions. See G. Driver \& J. Miles, supra note 133, at 6; R. Yaron, The Laws of Eshnunna 2 (1969). The laws found in the Old Testament are not thought to have been codified earlier than Hammurabi's Code, but it may be nseful to note that although Leviticus 19:16, for example, provides that "neither shalt thou stand idly by the blood of thy neighbor," it is not at all clear that such a provision carried witl it a sanction or was otherwise something other than a suggested moral standard. See 1 Pentateuch and Haftorahs 501 (J. Hertz ed. 1941). Similarly, the Old Testament requires one to "find" and return lost property. See Exodus 23:4-5. But, again, no penalty is indicated for the failure to rescue and no reward is provided to the rescuer. It may, of course, be quite significant that earlier codes announced such standards, but my point is that one might just as well say that modern American society condemns one who stands idly by while another is in danger and, yet, legislates no sticks for so many nonrescuers.

${ }^{135}$ Code of Hammurabi $\S 16$. All translations of Hammurabi's Code in this article are from C. Edwards, The Hammurabi Code (1904). 
gested for one who builds a sixty-ton boat (perhaps as a member of a typical work crew) and is twelve times the daily rental price of such a boat. ${ }^{136}$ On the other hand, the use of the word "field" in section 17 seems to imply that the fugitive was seized not on city streets but out in the country. It is therefore possible that the lawmaker meant to supply only a modest or even a skeleton carrot to the "rescuer," for the work and time required to seize a slave and transport him to the city could have been substantial. It is most unlikely that this effort would have equaled that required to build (or help build) a boat, but because there was surely a fair amount of risk involved in this sort of work, it is possible that potential rescuers would have regarded two shekels more as reimbursement than as enticement.

It would not, however, contradict the analysis in Part I of this article to discover that one who "rescued" lost slaves earned substantial rewards. It will be recalled that the drawbacks of a "no sticks and large carrots" incentive system include the problem of excessive precautions by potential victims, who will wish to avoid the payout of large carrots, and the moral hazard that emergencies will be created by profit seekers. But in the circumstances described in section 17 of Hammurabi's Code neither of these drawbacks is present. Slaveowners must have had a fair incentive to guard against escapes even in the absence of section 17. And the primary means of guarding against escapes would surely have been to promise slaves that large penalties would accompany their recapture. ${ }^{137}$ Indeed, the reward provided in section 17 might simply have worked to discourage escapes, for slaves would have known that strangers were encouraged by the law to help recapture escapees and strongly discouraged by the law from harboring them or helping them escape. ${ }^{138}$

136 Code of Hammurabi $\S 277$.

${ }^{137}$ See G. Driver \& J. Miles, supra note 133 , at $107 \mathrm{n} .6$ (presuming penalties by owner and noting that $\$ 282$ of the Code provides for removal of the ear of a slave who denies his master). It is difficult to imagine a flourishing slaveowning society in which inost slaves were constantly shackled or watched, for such precautions would be extremely costly. Work farms, for example, are hardly thought to be profit centers. Instead, an economically successful society such as Hammurabi's Babylon must surely have threatened potential escapees with punishment more than it would have constrained their movement.

13s Sections 15 and 19 of the Code of Hammurabi provide for the slaying of someone who accompanies an escaping slave or hides an escaped slave in his house. 
It is also likely that the moral hazard that typically accompanies large carrots would have been minimal in the circumstances addressed in Hammurabi's Code. A profit-seeking rescuer could, for example, have taken steps to ensure that a boat would soon require towing but it is hard to see how he could have increased the number of escaped slaves in order to profit from section 17. This potential "rescuer" was not in a position to promise a slave a share in the profit-and without a slave's cooperation, or escape, no capture would have been possible.

In short, unless there is evidence that in Hammurabi's day rewards were generally offered to finders and other unobliged rescuers, there is good reason to discount the likelihood that the "no sticks and large carrots" package provided for the capture of slaves was found in other contexts. The punishment of slaves after their return would have substituted for inefficient precaution-taking by slaveowners and would have more than offset the moral hazard affecting intermeddler-rescuers. There is, therefore, every reason to think that the drafter of the Code supposed a norm of "no sticks and no carrots" or "carrots and no sticks" but provided for "no sticks and large carrots" precisely where other factors worked to eliminate the usual drawbacks of such an unbalanced package.

The only other provisions in the Code that can possibly be said to deal with rescuers and their rewards provide that physicians earn extraordinarily large rewards for successful operations but must, when unsuccessful, pay compensation to their patients. ${ }^{139} \mathrm{~A}$ comparison of these provisions with those found today in American jurisdictions illustrates the uniformity-variety argument rather nicely. If the ancient Babylonians wished to impose liability on unsuccessful surgeons-perhaps because inevitable or nonnegligent fatalities were hard to separate out from those caused by negligent surgeons ${ }^{140}$ - then in order not to discourage aspiring surgeons (create a serious activity-level effect) it was surely necessary to allow surgeons to charge high fees or to legislate such fees for successful operations. It would have been disastrous to encourage suc-

139 Code of Hammurabi $\S 215$ provides: "If a doctor has treated a man with a metal knife for a severe wound, and has cured the man, or has opened a man's tumour with a metal knife, and cured a man's eye; then he shall receive ten shekels of silver." Code of Hammurabi § 218 provides: "If a doctor has treated a man with a metal knife for a severe wound, and has caused the man to die, or has opened a man's tumour with a metal knife, and destroyed the man's eye; his hands shall be cut off."

10 See Levmore, supra note 8. 
cess in surgical techniques with large carrots only, for the moral hazard of unlicensed surgeons' encouraging all strangers onto the operating table would have been too great. Carrots alone or sticks alone would clearly have been unwise. As between the two possible balanced packages, the lawmaker obviously rejected the laissezfaire "no sticks and no carrots"-perhaps because patients could not be expected to bargain wisely over the ramifications of their own nonrecovery-in favor of "sticks and carrots."

American law, by contrast, has adopted the "carrots and no sticks" package. Physicians are hardly held to a more gruehing liability standard than other members of society, are entitled to bargain for substantial compensation, and are almost uniquely able to collect their usual fees when noncontractually undertaking rescues. ${ }^{141}$ But, again, the unbalanced package is found precisely where the usual drawbacks are absent. It is surely easier for a profit-hungry physician to encourage elective surgery and excessive office visits than it is to create a medical emergency on the road (without incurring tort liability). Moreover, the larger moral hazard is controlled through licensing boards and professional standards-constraints that were surely less effective in Hammurabi's day. And potential victims already have every reason to take precautions against such emergencies; the potential cost of a doctor's services on the roadside will, for example, hardly change driving behavior. To be sure, moral hazard problems and excessive precautions might well be generated by an extremely unbalanced package that offered physicians very large carrots for their rescue efforts. But this is precisely the message of the uniformity-variety thesis; one should not expect to find a very unbalanced package in any legal system, but ainong relatively balanced packages variety is unsurprising for it is not obvious which package is best. In both American and Babylonian law we find that a balanced package is the norm but that physicians confront unique packages. In Hammurabi's Code it is a balanced package of carrots and sticks. In American law the balance is closer to "no sticks and no carrots," but the package is somewhat unbalanced with respect to emergency medical services-but this is precisely where an analysis of the usual drawbacks to unbalanced packages suggests that less balance is needed.

${ }^{141}$ See Landes \& Posner, supra note 19, at 109-11. 


\section{The Hittite Laws}

Assuming that section 17 of the Code of Hammurabi is limited to the capture of escaped slaves, the ancient Hittite laws appear to be the first to have designed carrots for finders, or rescuers in general. ${ }^{142}$ Whereas earlier rules merely prescribe that a finder of lost property should seek out its rightful owner, ${ }^{143}$ the Hittite laws contain the following provisions:

$\S 22$. If a slave escapes and anyone brings him back, if he finds him in the vicinity, he (the owner) shall give him shoes; if (he is caught) on this side of the river, he shall give him two shekels of silver; if on the other side of the river he shall give him three shekels of silver.

$\S 23$. If a slave escapes and goes to the country of Luiyas, to him who brings him back he (the owner) shall give him six shekels of silver. If a slave escapes and goes to an enemy country, he who brings him back shall himself take him.

\section{....}

$\S 45$. If anyone finds utensils, he shall return them to the owner and he shall reward him. But if he does not return them he is a thief.

$\cdots$

$\S 71$. If anyone finds an ox or a horse or a mule, he shall bring it to the royal gate. But if he finds it in the country, it shall be brought before the elders and he may continue to harness it. But if its owner finds it and receives it as it was, he shall not hold hin as a thief. If he does not bring it before the elders, he is a thief.

....

§ 79. If oxen stray into a field and the owner of the field finds them, he shall yoke them for one day, and when the stars come out, he shall return them to the owner.

Here, as in Hammurabi's Code, punishment of the recaptured slave was at the discretion of the slaveowner, ${ }^{144}$ and carrots but not

\footnotetext{
142 See supra note 134.
}

The Hittite civilization flourished in the fourteenth and fifteenth centuries B.C. 14 Encyclopedia Americana (1975). The Hittite "laws" found between 1906 and 1912 are probably a set of royal decrees and refer to an older set of laws. All references to and translations of Hittite law are from E. Neufeld, supra note 133.

${ }^{143}$ Deuteronomy 22:1-3, for example, provides that a finder must seek out the rightful owner of lost property but sets out no sanctions for finders who fail to carry out this obligation or injunction.

144 See supra note 137. 
sticks are used to encourage the "rescuer." That these carrots were graduated according to the distance the rescuer travelled simply reinforces the idea that these carrots may not have been large. ${ }^{145}$ Once again, the incentives facing slaves surely overwhelmed the problems of excessive precaution and moral hazard.

Section 45 extends this "carrots and no sticks" approach to utensils-and thus almost certainly to identifiable lost property in general. ${ }^{146}$ As the earlier analysis in Part I implies, we should expect to find "carrots and no sticks" in a number of legal systems; indeed if the carrots are not in cash or otherwise not very likely to generate moral hazard problems, this package seems superior to "no sticks and no carrots." Moral hazard problems may be less serious with regard to lost property than with regard to other rescues unless evil intermeddlers can be expected often to steal property and then come looking for a reward for its return. And even this potential moral hazard may be avoided if property reported as probably stolen by an owner does not later qualify as "lost" for purposes of the reward of section 45 .

The only difficulty in interpreting section 45 concerns its last provision. The preceding discussion assumed that the finder was labeled "a thief"-and would suffer some unstated punishment ${ }^{147}$-not if he simply ignored the lost utensils but only if he took possession of them. Similarly, the last provision in section 71 can be taken to mean that under Hittite law the finder is punished only if he commits some wrongful affirmative act. The most likely interpretation of the several sections then seems to be that a twopronged approach is legislated: (1) A carrot is offered to a finder who returns lost property; in the case of lost animals, the finder's reward is the use of the animal for one day (section 79), for the cost of feeding the animal can hardly be equal to the value of one day's work or animals would be worthless assets, and in the case of utensils the reward is left for the parties to work out; (2) a filing system is created for lost property that is expensive to transport and not immediately returnable to its owners. Utensils would have had family markings on them and, in any event, storage would

\footnotetext{
315 See supra text following note 136 .

146 The ownership of a utensil could have been ascertained through family markings on the utensils or through inquiries of local artisans. See E. Neufeld, supra note 133, at 163.

147 Id. at 161.
} 
have been relatively easy. But one who found lost animals in the country was encouraged by the Hittite laws not to bring them to town where upkeep would be more expensive but instead to bring word of their discovery to the elders who would match up finders and losers.

This interpretation is not perfectly elegant; it would be more convenient if section 79 preceded section 71 and if it, rather than section 71 , listed a variety of animals and thus signalled strongly that its rule was illustrative. Still, I think the "carrots and no sticks" package just described to be the best interpretation of these sections.

It would not, however, do great violence to the uniformity-variety thesis to suppose that sections 45 and 71 do impose criminal sanctions on one who ignores apparently lost property. Read this way, the Hittite rules form a seemingly balanced "sticks and carrots" package, which may or may not be better than "no sticks and no carrots." The important point is that it is virtually inconceivable that the ancient document describes a "large carrots only," "sticks only," or "sticks and large (moral hazard-inducing) carrots" approach.

\section{Mongolian Tribal Law}

As I have described elsewhere, ${ }^{148}$ the customary law of Mongolian tribes was full of "sharing" rules. A person who caused an accident in nonnegligent fashion, for example, might have incurred partial liability so that he and the victim shared the burden of the accident. ${ }^{149}$ Although Mongolian tribal law did not always provide for sharing, ${ }^{150}$ the presence of some sharing rules may lead one to expect the granting of recovery for rescue, for the rescuer and rescuee would then share in the good fortune of a successful outcome. But the treatment of rescue in these laws goes beyond that which might be said to follow from whatever underlying sense of justice generated the sharing rules. These laws are far better

\footnotetext{
248 Levmore, supra note 8. The Mongolian tribes referred to in the text were nomadic cattle breeders and occasional farmers. Their customary laws were recorded between 1229 and 1709. See V. Riasanovsky, supra note 133 , at $5,17,19$.

${ }^{249}$ Thus, if disease spread from A's cattle to B's cattle, A paid one-half the damages. V. Riasanovsky, supra note 133 , at 177 .

${ }^{150}$ For example, one who was injured while breaking another's horse was treated entirely at the owner's expense. Id. at 158.
} 
understood from the perspective of sensible packages of sticks and carrots (in light of their likely behavioral effects) than from a perspective that simply admires or expects the repeated use of sharing rules.

I have come across only two fragments of customary Mongolian law that deal with rescuers other than finders. The first comes from the Buriat Code of 1781: "Whoever does not come to the assistance of a perishing person is liable to corporal punishment, but whoever saves a perishing person is awarded a horse."151 It is not clear whether the horse was to be supplied by the rescuee or, somehow, by public officials. The latter possibility would seem to create real moral hazard problems, for $A$ and $B$ could conspire that one will rescue the other in order to extract a horse from the "taxpayers" at large. Both because the customary laws are elsewhere careful not to create opportunities for mischievous strategic behavior and because these laws generally set out the responsibilities of individuals and never explicitly speak of the expenditure of funds by the government, I think it fair to assume that the rescuee was to award a horse to the rescuer. In any event, the law clearly chooses a "sticks and carrots" approach-with relatively large sticks and carrots. I suspect-but I have no way of knowing-that evil intermeddlers were in some way successfully deterred from creating the demand for their own services and thus from "earning" horses. Nor is it possible to say whether in everyday life among the Buriats excessive precautions by potential victims might have been a concern or whether there were clear potential rescue spots, so that the sanction imposed for nonrescue might have created a counterproductive activity-level effect unless accompanied by a substantial carrot. It is clear, however, that the package offered was a balanced one.

The laws contain much more material regarding the rescuer we call a finder. The Buriats treated finders much as they did more traditional rescuers; sticks for nonreporting and a reward of ten percent for finding. ${ }^{152}$ Among the Kirghiz ${ }^{163}$ a finder was obliged to

15I See V. Riasanovsky, Customary Law of the Nomadic Tribes of Siheria 55 (1965).

182 See V. Riasanovsky, supra note 133, at 185 (providing that the owner was bound to give one-tenth to the finder and providing for corporal punishment for failing to report a find).

${ }^{163}$ The Kirghiz constituted a nomadic tribe in Siberia and Eastern Russia. They numbered more than three million at the beginning of the twentieth century. V. Riasanovsky, supra note 151 , at $7,8,13$. 
spread news of his find or report it to the district authorities. $\mathrm{He}$ received one-quarter of the value of the returned property (oneeighth in the case of cattle) "or whatever the master may give."154 If he hid his discovery he was simply "without honor." as our extralegal culture also looks unfavorably on one who fails to act, it is fair to describe the Kirghiz rule as "carrots and no sticks." If honor carried with it special privileges, then the Kirghiz' scheme was more balanced. Among the Tunguses, a finder received onetenth but if he hid the thing found, then upon its discovery the informer received the one-tenth and the first finder was subject to corporal punishment. ${ }^{158}$ It seems that a finder who simply ignored the lost property and went on his way would not have been punished, although it may be that such behavior is simply not addressed in the reported laws. The approach taken thus seems to have been of the "(substantial) carrots and no sticks" sort-with the carrots extended to informers as well as to finders. Among the Yakuts, a finder received a reward "in the measure of his labors and expenses" up to one-quarter the value of what was found and was treated as a thief if he concealed his find. ${ }^{157}$ The language just quoted implies that a one-tenth or even one-quarter commission may have only reimbursed the finder for his time and expenses and been viewed not at all as a large carrot. But either way, it is reasonable to conclude that the Yakuts, Tunguses, and Kirghiz offered finders "carrots and no sticks," while the Buriats opted for "carrots and sticks."

Finally, among the Kalmucks a fine was imposed on one who did not report the find of stray cattle. ${ }^{158}$ No provision is made for the reward of an honest finder. Inasmuch as the rule addresses stray cattle that "join a herd,"158 it is, unfortunately, not clear whether it might have been extended to include circumstances in which a finder simply iguored and passed by apparently lost animals or

\footnotetext{
154 Id. at 13.

155 Id.

158 Id. at 75.

${ }^{187}$ Id. at 88-89. The Yakuts inhabited North Central Asia and numbered about 250,000 at the beginning of the twentieth century. Id. at 87 .

${ }^{158}$ The Kalmucks originated in western Mongolia and migrated first to Tibet and then to the steppes of the lower Volga. V. Riasanovsky, supra note 133, at 244-45.

150 Id. at 276.
} 
even other property. A most interesting twist in the law of the Kalmucks concerns the disposition of found cattle that are turned over to the authorities but then not claimed. The law provides that after three years the cattle shall be sold and the proceeds spent on the poor. ${ }^{160}$ The law also calls for a reward "in proportion to the value of the saved cattle" for the rescue of cattle from "wolves, storms, blizzards or drowning in mud or wells."161 Inasmuch as there is no reward to the honest finder, for apparently he gets neither a commission from the owner nor the right to keep the property if it be unclaimed, the system appears to be either of the "sticks and no carrots" or the "no sticks and no carrots" variety. Only when he rescues cattle from a serious emergency, such as wolves or blizzards, is the rescuer treated to a carrot. Moreover, since there is clearly no stick provided for someone who fails to rescue cattle from blizzards, it appears that the Kalmucks deployed a "carrots and no sticks" package for daring rescues. This combination of rules is not terribly surprising. Even if mere finders were penalized for ignoring lost property, it is very possible that there would have been no activity-level effect under such a rule because it is difficult to identify and avoid potential finding spots. In contrast, it is easy to imagine that one could seek shelter when wolves howl or blizzards rage so that the withdrawal of sticks in the case of daring rescues may have worked to avoid counterproductive activity-level effects precisely in the circumstances where such effects might have been generated. It is possible that the potential liability for carrots might have caused excessive precautions in general-but it is hard to imagine that precautions against blizzards or wolves would have been any different if such liability were imposed, for the probability of serious loss once blizzards or wolves were on hand must have been very high. Similarly, while it is barely possible that evil intermeddlers might have been motivated by carrots to cause someone else's cattle to stray off and thus create the need for their own rescue services, it would have been much harder for such intermeddlers to stir up blizzards or bring on the wolves. In short, the Kalmucks' use of carrots (and possibly sticks) in some settings and not in others is neatly explained by an examination of the likely behavioral effects on owners and potential rescuers of these carrots and sticks.

100 Id.

161 Id, at 258. 
Although the Kalmucks' rules reflect a concern about moral hazard problems, a fair summary of the treatment of rescue in Mongolian tribal laws in general is that potential moral hazards influence the law much less than other factors. The discussion has already exhibited the regular use of carrots $^{\mathbf{1 6 2}}$-and while these carrots were surely designed to stimulate rescues and the return of lost property in particular they could, theoretically, induce evil intermeddling. Perhaps the best illustration of this faith in the predominance of the positive aspects of carrots is found in the Mongolian rule that a "witness is rewarded for helping justice: he receives nine animals out of the (criminal) fine and a certain part of the property in proportion to the quantity thereof judged by the court." $"$ As one might expect, this carrot was accompanied by a stick for false witness, ${ }^{164}$ but the interesting point is that variety is found among legal systems precisely where it might be expected by an aggressive application of theory. American law does not reward witnesses and promises a stick (a low probability of a perjury prosecution) to a dishonest witness. The stick seems unlikely to generate much of a marginal activity-level effect ${ }^{165}$ and a carrot seems unwise for moral hazard reasons, until one realizes that carrots can encourage unknown witnesses to come forward and can, at least in theory, be combined with sticks to discourage profit-seeking witnesses. That just such a package was found in Mongolian tribal law does not, of course, indicate that it is either culture-bound, superior, or inferior and intentionally abandoned in an evolutionary way. It is, instead, one more example of the way in which variety is found in a predictable range while uniformity-in the form of a balance between rewards and penalties-outside of this range is a rather durable phenomenon across legal systems.

\footnotetext{
${ }^{162}$ It is interesting to note that modern Mongolian law offers carrots to finders who return lost property. This carrot is equal to $10 \%$ of the value of the thing and is paid either by the owner or by the state, if the latter gains ownership because no private owner claims the lost property. W. Butler, The Mongolian Legal System 293 (1982) (translating article 100 of the Civil Code of the Mongolian People's Republic).

163 V. Riasanovsky, supra note 133 , at 93.

${ }^{164}$ For example, for falsely accusing another man of theft a fine is imposed and any unjust enrichment is extracted. Id. at 91. I assume that this rule (or an even harsher one) applied to witnesses as well as plaintiffs.

${ }^{165}$ See supra text accompanying note 32 .
} 


\section{The Future of Rescue}

There is no reason why the law regarding rescue could not remain just as it now is. There is no sudden outbreak of conflicting decisions or hostile public opinion on the matter. Concern about activity-level effects, excessive precautions, unwanted intermeddling, unnecessary judicial intervention in the private affairs of citizens, and the monetization of moral norms may forestall any changes in rescue law or even ensure that the clock is rolled back a bit and that "no sticks and no carrots" is practiced as well as advertised. On the other hand, courts may continue to designate special relationships ${ }^{168}$ and may often decide that rescuers shall recover for their expenses when rescuees were negligent; if so, the general rule will be "occasional sticks and infrequent carrots," rather than virtually none of each. Indeed, courts may even drop these preconditions to their own intervention. My intuition is that this second scenario, a steady evolution toward the European model of "sticks and carrots," is more likely. I think that I am not the only reader of these decisions who emerges with a strong sense that the law regarding salvors at sea and finders of lost property is much more stable than that dealing with disclosers of information and noncontractual rescuers. ${ }^{167}$ I would hardly argue that these four problems are so alike that the latter two are destined to be treated under the generous ${ }^{168}$ "carrots and no sticks" approach

${ }^{186}$ See supra notes 56-75 and accompanying text.

107 This assertion is difficult to support with hard evidence. My impression derives both from judicial decisions and from academic writings. No one suggests that salvors at sea receive carrots that are too large or too small or that sticks be used to encourage their efforts. The little debate that has inaterialized is focused on the rewards for pure life salvage-a tiny inlet, at most. Similarly, it is very difficult to find a judge or commentator suggesting reform of the law affecting finders. There is some problem in distinguishing mislaid from abandoned from lost property (compounded by a disinclination of courts to think in terms of probabilities), some movement toward statutory carrots, see supra note 85, and some discussion of the enforceability of rewards wben it is criminal not to return found property (but, interestingly, no discussion of the reward's role in causing the finder not to ignore the property). See Note, Rewards for the Return of Lost Property: Are Tbey Void in New York?, 24 St. John's L. Rev. 287 (1950). But these issues are quite minor when compared to the problem of motivating finders in general. In contrast, there is an enormous amount of discomfort and discussion regarding the duty to rescue. For a tip of the iceberg, see Woozley, A Duty to Rescue: Some Thoughts on Criminal Liability, 69 Va. L. Rev. 1273 (1983) (arguing for a criminal penalty for nonrescuers).

${ }^{160}$ By "generous" I refer to the fact that salvage awards provide for more than reimbursement and that finders are often allowed to keep unclaimed property. The expected value of 
that seems so unshakable with respect to salvors and finders. Sticks would surely create more of an activity-level effect on information production than on findings and rescues. And customized carrots, although used to encourage finders and disclosers, are understandably unenforceable when used by salvors and rescuers. ${ }^{160}$ However, I do think that there is much more judicial and legislative discomfort with respect to the treatment of rescuers than there is with regards to salvors and finders. In this discomfort may lie the seeds of change.

The aim of the discussion in this part is not, however, to demonstrate that the law of rescue is especially ripe for change. I argue instead that an important theme that runs through the rescue cases also appears in many important modern tort cases-and that the evolution of rescue law may track that of tort law. Tort law can be described in a manner that may first seem paradoxical as both imposing liability on the single party that is the least-cost avoider and as increasingly imposing some form of joint hability, rather than no liability, when no such single avoider exists. And rescue law can be described as expanding the obligations of potential rescuers precisely where a single party is the best or most obvious rescuer. Finally, it is possible that rescue law will now follow tort law and develop means with which to grapple with cases where no single potential rescuer stands out. The recent evolution of tort law may therefore give us a sense of the future of rescue law.

\section{A. Single and Multiple Accident-Avoiders in Tort Law}

The notion that much of tort law can be viewed as imposing liability on the party, or single avoider, best able to accomplish a socially desirable or "would-be-bargain" result needs no rehearsal.170 The search for a single and best avoider is easy to understand in terms of transaction costs. If no liability is imposed, then the victim, assuming he is not the best avoider, must try to contract with potential tortfeasors in order to avoid injury. ${ }^{171}$ Such bargains with

the finder's residual claim almost surely exceeds the cost of picking up and announcing the find.

${ }^{168}$ Disclosers are "offered" their customized carrots in negotiations with other parties. See supra text accompanying notes 101-04.

170 An excellent introduction (and summary) is found in R. Posner, Economic Analysis of Law, §§ 6.1-6.17, at 119-159 (2d ed. 1977).

${ }^{171}$ If A need not pay when he pollutes B's property, then B could bargain with A to avoid 
many unknown parties will obviously be difficult to accomplish. If the threat of liability hangs over multiple potential avoiders, then they may undertake duplicative precautions or may each hope that someone else avoids the accident so that no one in fact takes the necessary precaution. In short, when transaction costs are substantial, not only is the need for legal intervention clear but also the advantages of aiming that intervention at a single avoider are apparent. The single-avoider notion is somewhat contradicted by the evolution of products liability law where a plaintiff can now sue both the manufacturer and the dealer of the product he regards as defective; ${ }^{172}$ but it is fairly clear that in these cases the contractual ties between the potential defendants must usually be thick enough to overcome the potential for duplicative or inadequate precautions that normally exists with multiple potential avoiders. ${ }^{173}$

In more complex settings the problems posed by multiple parties are not so easily solved by imposing liability on a single avoider. There is, I think, no paradox in suggesting that when singleavoider solutions are feasible tort law evolves toward such solutions, but that when multiple party problems are endemic tort law will simply try to solve the deterrence problem as well as possible. Broadly speaking, the multiple party problems are of two types, interactive and horizontal. By interactive I refer to circumstances in which harms can be prevented by multiple parties acting jointly or alternatively. The manufacturer who can add more safety devices to a machine and the consumer who uses this machine are examples of such interactive parties. In such settings, the ideal behavior of one party depends on the behavior of another, whose own ideal behavior depends in turn on expectations about the first party's behavior. ${ }^{174}$ Unless the parties that are involved and the factfinder that reviews the situation later are extremely well-in-

some or all of such pollution.

172 See W. Prosser \& W. Keeton, supra note $1, \S 100$, at 703-07.

173 Moreover, manufacturers are often such attractive defendants that plaintiffs may not even hother to sue both the manufacturer and the retailer (with whom there was privity) of the allegedly defective and injury-causing product.

174 Joint care refers to a situation in which $\mathrm{A}$ and $\mathrm{B}$ must take steps to avoid a harm (to themselves or to some other party). Alternative care refers to a setting in which A or B can take a step to avoid an injury. Some circumstances involve both, as when $\mathrm{A}$ can spend 30 to avoid a harm (of 100 , say) or B can spend 35 to avoid the same harm or A can spend 14 and $B$ can spend 10 to avoid the harm (jointly). 
formed, these interactive (multiple party) problems are confounding. ${ }^{178}$ Tort law has experimented with different kinds of liability rules including various contributory and comparative negligence rules, but no rule is quite the match for the problem. ${ }^{176}$ I think it fair to say that the direction of change has been toward partial recovery; comparative negligence rules, under which liability is spread among parties who might have taken accident-avoiding steps, have become increasingly popular.

"Horizontal" problems involve multiple misbehaving or potentially misbehaving parties (whose ideal behavior depends very little on that of other parties) and uncertainty regarding which of these parties caused a particular harm. The law has had great difficulty in settling on rules that best "match" injured plaintiffs with those negligent defendants who truly caused their injuries. ${ }^{177}$ The law dealing with these horizontal problems is hardly settled, but it is at least arguable that recoveries are unlikely when there is a horizontal matching problem with limited misbehavior, as when plaintiff only knows that he was hit by a bus and more than one party might have owned the bus that hit him, ${ }^{178}$ but that probabilistic recoveries are increasingly likely when horizontally aligned defendants have all misbehaved, as when plaintiff's injury is caused by a defective drug manufactured by one untraceable member of a group of unrelated companies making the same product. ${ }^{179}$ This re-

${ }^{175}$ The factfinder must know the precise least-cost solution.
${ }^{178}$ See supra note 175 .
${ }^{177}$ See generally Kaye, The Limits of the Preponderance of the Evidence Standard: Justifiably Naked Statistical Evidence and Multiple Causation, 1982 Am. B. Found. Res. J. 487 (analyzing the use of statistical probabilities to apportion error among several defendants); Robinson, Multiple Causation in Tort Law: Reflections on the DES Cases, $68 \mathrm{Va}$. L. Rev. 713 (1982) (damages should be apportioned among all defendants that created unreasonable risks according to the magnitude of the risks created). The "matching" idea comes from Sindell v. Abbott Laboratories, 26 Cal. 3d 588, 607 P.2d 924, 163 Cal. Rptr. 132 (1980).

${ }^{178}$ See Smith v. Rapid Transit, 317 Mass. 469, 58 N.E.2d 754 (1945). But see Kaminsky v. Hertz Corp. 94 Mich. App. 356, 288 N.W.2d 426 (Ct. App. 1979) (refusing to dismiss case where $90 \%$ chance that truck was owned by defendant).

${ }^{179}$ See Hardy v. Johns-Manville Corp., 509 F. Supp. 1353 (E.D.Tex. 1980) rev'd on other grounds, 681 F2d 334 (5th cir. 1982) (concluding that Texas courts would adopt the Sindell approach to apportionment); Sindell v. Abbott Laborateries, 26 Cal. 3d 588, 607 P.2d 924, 163 Cal. Rptr. 132 (1980) (defendant drug manufacturers required to pay a proportional share of the judgment as represented by their respective market shares). As a matter of positive and even of normative theory, I think an important element of these cases is that they involve defendants who are involved with numerous plaintiffs. As such, "averaging" may seem more equitable and efficient because it becomes quite likely that tortfeasors and 
view of single and multiple tortfeasors, or potential accidentavoiders, sets the stage for a discussion of single and multiple omitters, or potential rescuers. As we will see, the increasing willingness of courts to accept probabilistic causation arguments in cases involving multiple tortfeasors may signal-at least as a logical matter-a willingness to accept similar causation arguments that must underlie claims that assert a duty to rescue.

\section{B. Single and Multiple Potential Rescuers}

I have not meant to use this article as a forum for the view that the imposition of tort liability is always a good thing when a single avoider can be identified or that it is not a good thing when interactive or horizontal multiple party problems are unavoidable. Similarly, I do not wish to contend that no duty to rescue should be imposed unless there is clearly a single potential rescuer to motivate with sticks and carrots. Instead, I have only noted that as a descriptive matter tort law can be characterized as searching for a single best avoider, but increasingly imposing liability when there are multiple avoiders and no single best avoider. Similarly, the discussion in this section now links the growth in hability for potential rescuers who have special relationships with victims to the notion of the single rescuer. Although this hink is promoted in this article as descriptively useful, it is worthwhile-if only because positive arguments are more appealing when they are coextensive with arguments that are normatively plausible-to explore the reasons why lawmakers might limit sticks (or sticks and carrots) to circumstances in which there is a clear single potential rescuer. Such an exploration is undertaken below, following the establishment of the link between the duty to rescue and the notion of a single potential rescuer.

When a victim's call for help goes unanswered, there may be more than one potential rescuer within hearing range. Indeed, it must often be the case that when B could have rescued A, B's presence at the scene only comes to the attention of the law because other potential (and often unhelpful) rescuers, C and D, were also at the scene of A's trouble. Such multiple potential rescuers pose a

victims will be properly "matched" over the entire set of cases. This is a topic that is, unfortunately, quite beyond the territory of the present article. 
doctrinal problem; if no rescue is attempted, it will be unclear whether B, C, or D "caused" A's injury-and misbehavior without causation of an injury is traditionally an insufficient basis for liability. The problem may not seem any different from one in which two hunters negligently shoot in the direction of a third person in their party and one (but it is unclear which) hits this unintended mark. ${ }^{180}$ The hunters will, of course, be held jointly and severally liable. ${ }^{181}$ Apart from insisting that three potential causal agents present a very different problem than do two, there are at least three ways to distinguish the multiple nonrescuers from the multiple shooters. First, one can simply follow the traditional hine and insist that the law distinguishes omissions from commissions. This route will not be a terribly successful one both because some omissions, such as draft evasion and tax evasion, are seriously and understandably penalized and because, as reviewed presently, rescue is often obligatory.

Second, it is arguable that the causation problem in rescue goes to the root of negligence so that rescue cases are more like the bus case, ${ }^{182}$ in which only one actor is negligent and none is held liable, than like the shooting or defective drug cases, in which all actors are negligent and at least partially liable. In rescue cases, after all, if $B$ rescues A, C and D's inaction is perfectly acceptable in both legal and moral terms. As such, because in many cases each potential rescuer is probably unaware of the actions of other potential rescuers, it is conceivable, even if horrible, that each behaves nonnegligently because each thinks that there is no need for his own efforts. On the other hand, no hunter should shoot in the direction of a camouflaged buddy and no drug manufacturer should turn out

\footnotetext{
${ }^{180}$ See Summers v. Tice, 33 Cal. 2d 80, 199 P.2d 1 (1948) (both hunters hit the unfortunate victim, but the litigation concerns the more serious injury). It is arguable that the more relevant analogy is to the cases in which both defendants do wrong and both injure plaintiff, as when two negligently set fires consume plaintiff's property. See Kingston v. Chicago \& N.W. Ry. 191 Wis. 610, 211 N.W. 913 (1927) (when two "unnatural" fires cause damage, both firestarters will he liable jointly and severally, and if only one firestarter is known it is he who will be liable for the full annount of the dainages). But as the text goes on to discuss, neither analogy is quite perfect, for when there are multiple nonrescuers any one defendant could have saved the day. The tort cases, on the other hand, concern defendants who might not have added to the harm at issue.

${ }_{181}$ See Hall v. E.I. du Pont de Nemours \& Co., 345 F. Supp. 353 (E.D.N.Y. 1972); Summers v. Tice, 33 Cal. 2d 80, 199 P.2d 1 (1948); Restatement (Second) of Torts $\S 433 B$, illustration 9 (1965).

${ }^{182}$ See supra note 178 and accompanying text.
} 
defective drugs regardless of the actions of fellow hunters and manufacturers. I must add that my own normative view is that this distinction is unimportant. It may he sensible to deny recovery to a plaintiff who offers only probabilistic evidence regarding which of a number of bus companies caused his injury because in many cases this rule might lead plaintiffs to investigate further and identify their tortfeasors more precisely. In contrast, the probabilistic basis for believing that a nonrescuer may not have been negligent is not capable of being altered after the fact. The problems of probabilistic proof and probabilistic need for rescue are thus different. Still, I advance this second argument for distinguishing multiple nonrescue from multiple tortious behavior because it is certainly possible that it is this sort of argument that has caused judges to hold multiple shooters and not multiple nonrescuers liable.

A third difference between multiple nonrescue and negligence may be one of time and not substance. Tort law has only recently evolved to the point of assigning liability in probabilistic fashion among numerous defendants. Two neghigent hunters seemed to present an easy case, perhaps because the probability of a "match" was just one percent below that required in the usual more-likelythan-not test. But multiple drug manufactuers would almost surely not have been liable twenty or fifty years ago unless the probability of a match between a plaintiff and a given manufacturer was also in the fifty-percent range. It is thus arguable that multiple nonrescue and multiple affirmative negligence were treated alike for many years and that evolution or experimentation has recently affected the treatment of the latter only so that we are now in a developmental period in which multiple negligent parties but not multiple nonrescuers incur liability. This argument suggests that the law may change in either area once again and multiple nonrescuers and multiple negligent tortfeasors will then be similarly treated.

A single identifiable nonrescuer, however, presents no matching or deterrence difficulties and is very much like a paradigmatic single tortfeasor. To be sure, it is possible to insist that nonrescue always presents the problem of multiple parties. When, for example, A's surviving family learns that $B$ could have rescued $A$, it is always possible that $C$ and $D$ could also have effected a rescue but that their identities or presence at the scene of A's tragedy remains 
unknown. But this uncertainty alone should not lead one to expect that single nonrescuers will be excused from liability, because this is the sort of uncertainty that the tort system frequently indulges. When Z's negligently started fire sweeps across X's property, Z may be liable even though $\mathrm{Y}$ may also have started a fire that was on its way but is now unknown-perhaps because Z's fire consumed the evidence of its origins and path. The case presents no difficulty; $\mathrm{X}$ bears the burden of proving that there was at least one negligently set fire, and $\mathrm{Z}$ can only escape full liability by identifying $Y$ and then passing on the blame, sharing it, or seeking contribution. ${ }^{183}$ The remote possibility that a negligent $Y$ was involved but that $\mathrm{Z}$ is unable to identify $\mathrm{Y}$ and prove $\mathrm{Y}$ 's involvement is hardly allowed to interfere with Z's liabihty to X. Similarly, the mere possibility of multiple nonrescuers is unlikely to interfere with the liability of a single identifiable nonrescuer.

But the most important reason to think that the failure to rescue is really not so different from the commission of a negligent act is that, as indicated earlier, ${ }^{184}$ courts have discovered a surprising number of special relationships as bases for the imposition of duties to rescue. Most significantly, these special relationships have one thing in common: when there is a special relationship there is no multiple nonrescuer problem, for such a relationship is pronounced only in circumstances in which there is one identifiable or best-situated nonrescuer. This is not to say that whenever there is but one nonrescuer, courts will insist that he and the victim had a special relationship out of which a duty to rescue arose. The presence of a single nonrescuer is at present a necessary but not a sufficient condition for liability; it is the growing number of special relationships that indicates an increasing likelihood of liability on the single nonrescuer. As indicated earlier, ${ }^{185}$ the most remarkable thing about these cases in which special relationships are found is that some involve a single nonrescuer and a stranger. Liability has been found appropriate for an innkeeper who could have protected

\footnotetext{
${ }^{183}$ See Kingston v. Chicago \& N.W. Ry., 191 Wis. 610, 211 N.W. 913 (1927). But see Carpenter, Concurrent Causation, 83 U. Pa. L. Rev. 941 (1935) (discussing cases that reject the Kingston principle and refuse to find liability unless defendant's negligence was a substantial factor in the cause of plaintiff's injury). On contribution, indemnity, and apportionment, see W. Prosser \& W. Keeton, supra note 1, \$\$ 50-52, at 336-55.

${ }^{184}$ See supra text accompanying notes 56-77.

185 See supra note 77 and accoinpanying text.
} 
a stranger from injury by one of the innkeeper's guests, ${ }^{186}$ a safety engineer who could have prevented an injury to a laborer he did not employ, ${ }^{187}$ a psychologist who might have warned an identifiable stranger his patient was intent on harming, ${ }^{188}$ and, similarly, a parole board, acting as a single entity, that might have warned someone who was the target of a released convict. ${ }^{189}$ In these cases, there is of course no "relationship" at all. Instead, these cases contain three elements. First, there is a single nonrescuer. Second, this nonrescuer could with little effort have prevented a serious loss. Third, this nonrescuer had no reason to think that someone else would save the day. In short, although I think that a single nonrescuer is not very different from a single negligent tortfeasor, it is hardly arguable that the two are treated the same under current law. But it is arguable that nonrescuers are increasingly incurring liability and that through the concept of special relationships this liability is most often imposed precisely where there is a clear, single nonrescuer.

There is another clue that suggests in a striking way that the major obstacle to holding nonrescuers liable is the historical disinclination to impose liability where multiple parties are at fault. It has long been the case that if $B$ begins to rescue $A$ but then abandons the rescue effort, then $B$ will often be held liable for nonrescue even though he is said to have had no duty to rescue in the first place. ${ }^{190}$ Occasionally, B may have made A worse off by leaving him in a place where other rescuers were less likely to help or simply by using up time in which other rescuers might have appeared. But it is rather clear that courts do not look carefully for evidence of such causation but instead often hold B liable for what might be regarded as active, or conscious, nonrescue. ${ }^{101}$ Clearly, B's initial efforts single him out and "solve" any multiple party problem. B's false start allows the law to identify him-as opposed to

\footnotetext{
${ }^{188}$ See supra note 57.

${ }^{187}$ See supra note 67.

${ }^{188}$ See supra note 69 .

${ }^{180}$ See supra note 72.

100 See W. Prosser \& W. Keeton, supra note $1, \S 56$, at 378.

101 Id. $\S 56$, at $378-82$. For cases in which the volunteer made things worse, see id. $\S 56$, at 378 n.55, $381 \mathrm{nn} .83-85$. To the extent that those who undertake (and then drop) a rescue attempt move a victim or appear to passers-by to have the situation under control, I think it plausible that their liability derives in part from a sense that the victim would have been better off without such an attempt.
} 
other potential rescuers-as the nonrescuer and to see him in a light that is so similar to that which falls on a typical tortfeasor. The inclination to hold the "withdrawing rescuer," $\mathrm{B}$, liable is thus a further indication that it is the problem of multiple nonrescuers that is at the heart of any difference between omissions and commissions. ${ }^{192}$ Similarly, the admiralty law rule that a vessel involved in a collision must "stand by" to assist the other vessel or be rebuttably presumed to have been at fault is, like attitudes towards a hit-and-run driver on land, an example of the imposition of an affirmitive obligation where an identifiable, single and obviously least-cost rescuer is on hand. ${ }^{193}$

These arguments-that there is not a convincing analytic difference between the case involving two negligent hunters and that involving two nonrescuers and that the expansion of special relationships is no more or less than the gradual (if slow) imposition of a duty to rescue on single identifiable potential rescuers-lead to fairly specific predictions about the future of the use of sticks in rescue law. First, there is every reason to think that nonrescuers will increasingly be held liable, even in the absence of further statutory innovation. Second, multiple nonrescuers may also be held liable in the future, for now that tort law has grappled with multiple parties there is less reason to think that rescue law will not do the same. Finally, although this section has focused on sticks and not on carrots, it is useful to repeat the thesis developed early in Part II: American law may already provide at least skeleton carrots to many rescuers. Whether or not the expansion of special relationships will mean not only that an identifiable A might be liable for not rescuing $B$ but also that $A$ could collect his expenses (or more) from $B$ is a difficult question. Many of the special relationships that, at least at first, link A and B are contractual, so that A could collect "negotiated carrots" from B. Landlords and psychologists, for example, could surely raise rents and fees to finance the cost of their increased precautions (or liability). ${ }^{194}$ It is, in short, possible

192 Similarly, "hit-and-run driver" statutes, which impose liability for failure to stop and "rescue," see id. $\$ 56$, at 377 , are easily described as imposing liability on the best positioned single party who will realize that it is unhikely that someone else will save the day.

${ }_{193}$ See G. Gilmore and C. Black, supra note 103, at 490-91.

194 Obviously these increased prices will decrease the demand for that which landlords and psychiatrists offer. Still, in a competitive environment prices will eventually he related to the average cost of production so that consumers will pay for the precautions they enjoy. 
that American law will raise the rewards offered to potential rescuers but also possible that it will, instead, simply leave these rewards to market forces. If liability for nonrescue extends one day to all single or even multiple nonrescuers, then it is most likely that skeleton or statutory carrots will continue to sprout. ${ }^{195}$

\section{Conclusion}

I have tried in this article to make a comparative claim and a predictive claim and to base both on the likely behavioral effects of legal rules affecting potential rescuers. The comparative, or historical, claim is that certain combinations of penalties and rewards are more attractive than others-and that different legal systems should be found to have selected from the most attractive sets. The prediction is a bit more restrained: American jurisdictions may increasingly impose liability for failure to rescue much as they have increasingly imposed tort liability in general. There is also every reason to believe that carrots will accompany these sticks. My greatest hesitation in predicting these developments in American law concerns the evolution of the treatment of multiple committers. The decisions that have allowed probablistic claims against multiple defendants have insisted that a large percentage of such defendants be included in the claims and have concerned cases in which the multiple defendants' behavior or products were virtually identical. ${ }^{196}$ In addition, the behavior of all the defendants in these cases needs to be altered, while in multiple nonrescuer cases only one rescuer is usually needed. Tort law does not yet contain decisions that directly stretch interactive or horizontal liability to cases in which multiple parties do different neghgent things-only one of which caused an injury-so that an injured plaintiff could recover from all jointly and severally or from each for a small percentage of the total claim. ${ }^{197}$ In the famous

\footnotetext{
${ }^{195}$ Such carrots have already sprouted in the form of Good Samaritan statutes. See supra notes $45-81$ and accompanying text.

${ }^{106}$ See Sindell v. Abbott Laboratories, 26 Cal. 3d 586, 612, 607 P.2d 924, 936, 163 Cal. Rptr. 132, 145 (1980) (implying that when 90\% included, "substantial percentage" requirement met).

197 See Robinson, supra note 177, at 749-68. Of course, decisions that use the doctrines of comparative negligence and proximate cause may accomplish such results in subtle ways. The point in the text is simply tbat it would be regarded as quite pathbreaking for a judge to spread liability in a setting in which A's injury had some small probability of being
} 
Kitty Genovese incident, for example, in which every one of thirtyeight witnesses to a horrihle assault failed to call the police or otherwise assist the victim, ${ }^{198}$ liability in the manner of tort law would have required separate inquiries into the costs that each potential rescuer would have needed to overcome, calculations regarding the probability that a rescue would have been successful, and discounting for the relative contribution of each of the nonrescuers. The possibility that sticks will one day be imposed for such nonrescue behavior must not be entirely dismissed, but it is not clear that such probabilistically small commissions will be penalized and certainly not hikely that penalties for omissions will develop ahead of those for commissions. ${ }^{198}$

There is, however, the possibility that the law will offer "carrots only" rather than "sticks and carrots" or even "sticks only." These carrots may need to be developed further in legislative rather than judicial chambers ${ }^{200}$ and would, presumably, only be developed by lawmakers who thought that any moral hazard problems were relatively small. The evolution of tort law for commissions is unhelpful in predicting the further evolution of carrots, for while the identification of a single rescuer or a limited number of rescuers is often possible, the identification of a single non-tortfeasor is usually not possible. It is obviously not feasible to reward all those who do not negligently shoot guns or pollute but it is feasible to reward one who first assists a victim in an emergency. ${ }^{201} \mathrm{I}$ am left with the sense that it would be rash to predict that sticks will be applied in cases where there are many or many differently situated nonrescuers. But it is far easier to predict that sticks will be imposed for less complex cases of nonrescue, that carrots will accompany these

caused by each of ten different defendants in ten different ways.

188 See B. Latane \& J. Darley, The Unresponsive Bystander: Why Doesn't He Help? 1-4 (1970); A. Rosenthal, Thirty-Eight Witnesses (1964) (describing the details of the assault in which Kitty Genovese was stabbed to death over a forty-five minute period).

199 For a more complete discussion of the ways in which comparative negligence might be used to address this problem, see S. Levmore, The Tort System (forthcoming).

${ }^{200}$ It is easy to imagine judges' holding that rescuers are entitled to reimbursement, but very difficult to conceive of judges' allowing recovery for more than skeleton carrots. There are, of course, analogies such as salvage to draw upon, but such a move seems more likely in legislative chambers.

${ }^{201}$ See generally Wittman, Liability for Harm or Restitution for Benefit, $13 \mathrm{~J}$. Legal Stud. 57 (1984) (using an economic model to describe why governments tend to rely on coercion as opposed to positive incentives). 
sticks, and that carrots may be extended to rescuers (privately, judicially, or legislatively) even in circumstances that sticks never reach. 
HeinOnline -- 72 Va. L. Rev. 9421986 